\author{
Dorota Angutek \\ dorota.angutek@wp.pl \\ Wydział Pedagogiki, Psychologii i Socjologii \\ Instytut Socjologii \\ Uniwersytet Zielonogórski
}

\title{
REKONSTRUKCJA LUDOWEGO HAFTU KRAJEŃSKIEGO: STAN BADAŃ, POCHODZENIE I WZÓR
}

\author{
Reconstruction of Folk Embroidery of Crayna - \\ Past Researches, the Origin, and the Pattern
}

\begin{abstract}
Streszczenie: Artykuł obejmuje rekonstrukcję dotąd nie uznanego przez etnografów haftu krajeńskiego z okolic Złotowa. Pierwsze trzy części artykułu mają charakter etnograficzny, zaś ostatnia antropologiczny. Dorota Angutek stawia tezę, że haft krajeński jest pochodną haftu kaszubskiego opracowanego przez Teodorę Gulgowską, jednak jego projektant pozostaje do dziś nieznany. W części pierwszej autorka przedstawia dotąd wykonane prace etnograficzne i amatorskie nad odtworzeniem ludowego haftu krajeńskiego; dokonuje ich typizacji. Współczesny haft krajeński przeniesiony na pozostałe obszary Krajny - powiat pilski, nakielski i sępoleński - jest fenomenem niewystępującym wcześniej na tych terenach i tworzy tzw. tradycję wytworzoną. Część druga artykułu wskazuje na koneksje historyczne i formalne haftu kaszubskiego i krajeńskiego oraz zawiera prezentację i interpretację dostępnych w muzeach Pomorza eksponatów z I połowy XX wieku. Ostatnia część pracy stanowi opis formalnych cech tego haftu od motywów, przez kompozycje, po ściegi, a kończy się omówieniem niektórych niekanonicznych rozwiązań stosowanych $\mathrm{w}$ hafcie krajeńskim w ciągu ostatnich dwudziestu lat.
\end{abstract}

Słowa kluczowe: haft krajeński; historia badań; pochodzenie; rekonstrukcja wzoru.

Abstract: The article contains reconstruction do not recognized by ethnographers Craynian embroidery from locality of Złotów. The first three parts of the article have an ethnographic character, and the last one is anthropological part Dorota Angutek puts thesis that Craynian embroidery is derived of Kashubian one worked out by Teodora Gulgowska, although its designer is unknown until now. In the first part the author presents ethnographic and amateurish works which has been done until now for reconstruction of folk embroidery of Crayna; she invents types of them. Contemporary Craynian embroidery which was transferred on others areas of Crayna - administrative districts of Piła, Nakło and Sępólno is a phenomenon not attended on this part of region of Crayna before, and it is so called invented tradition. The second part of the article indicates historical and formal connections between Kashubian and Craynian embroidery, and contains presentation and interpretation of attainable exhibits museums of Pomerania in the first half of XX 
century. The last part of the work makes description of formal features of this embroidery beginning from themes, by compositions to stitches, and moreover it includes not canonic solutions put in practice of Craynian embroidering during last twenty years.

Keywords: Craynian embroider; history of investigations; origin; reconstruction of pattern.

\section{Wstęp}

Haft ludowy z Krajny Złotowskiej, znany jako haft krajeński ${ }^{1}$, dotąd nie został przez etnografów ani wyczerpująco opracowany, ani też zaakceptowany jako taki. Nie tylko w gronie niektórych profesjonalistów, ale i w potocznym przekonaniu utrwalił się niesłuszny pogląd, jakoby jego powstanie było efektem inwencji i pomysłowości członkiń koła hafciarskiego z Więcborka. Tym samym neguje się dane przemawiające za jego historycznie ugruntowanym pochodzeniem. Wyniki żmudnych badań archiwalnych i terenowych prowadzonych przeze mnie w latach 2004-2016, z przerwami, na Pomorzu Wschodnim i Środkowym pozwalają stwierdzić, że haft krajeński posiada swoją złożoną genezę. Hafciarki z Więcborka jedynie skopiowały wzór ludowego haftu ze Skica, tkaniny znajdującej w Starej Świętej w chacie krajeńskiej (muzeum in situ; obie miejscowości leżą na obszarze Krajny Złotowskiej), pochodzącego z fragmentu brzegu halki datowanego na 1910 r. (Fot. 1, 2). Stworzyły na tej podstawie wzornik i rozpowszechniły wzór owego haftu na obszarze Krajny Nakielskiej ${ }^{2}$ oraz na imprezach ogólnopolskich. Dzięki muzealnikom - Janowi Niedżwieckiemu i Halinie Mikułowskiej (o nich dalej w tekście) - oraz hafciarkom z Więcborka haft złotowski nazywany „krajeńskim”, został replikowany i rozpowszechniony po okresie jego zapomnienia, który trwał od końca drugiej wojny światowej do końca lat 70. XX wieku.

W artykule koncentruję się na pięciu kwestiach. Na początku przedstawiam krótką relację z wykonanych już prac nad odtworzeniem haftu wywodzącego się ze Starej Świętej i Skica, powszechnie znanego jako haft krajeński. Celem owego

\footnotetext{
${ }^{1}$ Będę posługiwać się określeniem „haft krajeński”, gdyż nazwa ta obecnie funkcjonuje w nazewnictwie muzealników Pomorza i jest rozpowszechniona w potocznym obiegu. Określenie „haft złotowski" byłoby nieadekwatne wobec aktualnego zasięgu tego haftu, obejmującego całą Krajnę, aczkolwiek nazwa ta $\mathrm{z}$ historycznego punktu widzenia byłaby bardziej precyzyjna. Haft krajeński nazywam także „ludowym”, ponieważ wywodzi się on wprost z tradycyjnej kultury chłopskiej, która występowała przed drugą wojną światową na Krajnie, a więc także na terenie Starej Świętej, skąd pozyskane zostały prze Jana Niedźwieckiego zdobione tym haftem tkaniny znajdujące się $\mathrm{w} \mathrm{Mu}$ zeum Ziemi Złotowskiej w Złotowie.

${ }^{2}$ Krajna dzieli się na dwa subregiony: Krajnę Złotowską i Krajnę Nakielską.
} 
zestawienia prac rekonstrukcyjnych jest udokumentowanie występowania w ich ramach stałej tendencji polegającej na nawiązywaniu do historycznych wzorów haftu ludowego ze Starej Świętej. Kolejne cele nawiązują do pierwszego z wymienionych. Zatem drugim celem jest wykazanie, że haft krajeński, który został współcześnie spopularyzowany na całej Krajnie, zarówno Złotowskiej, jak i Nakielskiej, występował na Krajnie Złotowskiej w pierwszych czterech dekadach XX wieku (jego wzory zostały umieszczone na tkaninach, które znajdują się w zbiorach Muzeum Ziemi Złotowskiej w Złotowie). Po trzecie pragnę wykazać, że współczesny wzór haftu krajeńskiego, który jest wykonywany przez członkinie kół hafciarskich i osoby niezrzeszone opiera się na owych historycznych wzorcach ludowych i wykazuję, że haft współczesny jest zakorzeniony genetycznie w historycznym ludowym hafcie krajeńskim. Fakt ów daje podstawę do uznania współczesnej wytwórczości hafciarskiej opartej na wzorach ludowych za rdzenną regionalną krajeńską twórczość hafciarską ${ }^{3}$. Po czwarte zakładam i pragnę dowieść, że haft krajeński wywodzi się $\mathrm{z}$ haftu kaszubskiego. Przypuszczalnie jego twórcy działający w pierwszych dekadach XX wieku opierali się na popularnych na Krajnie Złotowskiej wzorach szkoły wdzydzkiej; jego powielaniem trudniły się dość powszechnie hafciarki zrzeszone w różnego rodzaju kółkach w Radawnicy, Złotowie, Kulkowie, Stawnicy, Głomsku. Czynię takie założenie, ponieważ zaobserwowałam formalne podobieństwa w stylu i wzornictwie haftów z obu regionów - Kaszub i Krajny Złotowskiej. Celem piątym jest przedstawienie wzoru haftu krajeńskiego, jego motywów, zasad kompozycji, kolorystyki i ściegów i wykazanie, że posiada on cechy haftu ludowego.

Część pierwsza artykułu obejmuje krótkie sprawozdanie z przeprowadzonych przez moich poprzedników prac rekonstrukcyjnych nad haftem krajeńskim. Prezentuję w niej także typizację przeprowadzonych badań etnograficznych oraz poszukiwania podjęte przez członkinie koła hafciarskiego z Więcborka. W drugiej części tekstu przedstawiam pochodzenie tego haftu zgodnie z hipotezą, że wywodzi się on z haftu kaszubskiego, zaś jego motywy odzwierciedlają wartości ważne dla chłopa polskiego w XIX i XX wieku, a zatem kult maryjny mający wyprosić szczególną opiekę Matki Bożej nad pracującymi na roli. Opracowanie genezy dotyczy

\footnotetext{
${ }^{3}$ Oczywiście istnieje potencjalnie możliwość wytworzenia współczesnego wzoru danego haftu, ale w przypadku haftu krajeńskiego nawiązano do wzorów ludowych w sensie genetycznym i formalnym, a ambicja, którą kierowali się kontynuatorzy tego wzornictwa miała za cel podjęcie w sposób niezmieniony kanonu ludowego opartego na haftowanych tkaninach pochodzących ze Starej Świętej i Skica.
} 
analizy zbieżności cech formalnych obu haftów na podstawie wybranych motywów haftu na Kaszubach, z uwzględnieniem XVIII-wiecznego białego haftu kościelnego i kaszubskich wzorów oraz krajeńskiego haftu ze Starej Świętej k. Złotowa. Część trzecia zawiera szczegółowy etnograficzny opis wzoru haftu krajeńskiego - motywy, kompozycje, ściegi, kolorystykę. Z konieczności pominęłam tu szereg wątków historyczno-kulturowych dotyczących kontekstu powstania tego haftu oraz faktów związanych z jego trwaniem w ostatnich latach ${ }^{4}$. Artykuł zamykają rozważania na temat zasadności utrzymania konwencji ludowej owego haftu i możliwości wzbogacenia go o nowe elementy.

\section{Stan wiedzy oraz typy etnograficznych i amatorskich badań nad ludowym haftem krajeńskim}

Jan Niedżwiecki, nieżyjący już dyrektor Muzeum w Złotowie, był pierwszym etnografem, który na początku lat 70. XX wieku postawił hipotezę o istnieniu ludowego haftu krajeńskiego na Krajnie Złotowskiej (Niedżwiecki 1977a: 119-120, 123; 1977b: 38; 2001: 168-171). Optował on za kaszubskim pochodzeniem haftu, którą to tezę podtrzymuję. Dokonał rekonstrukcji wzorów tego haftu przede wszystkim na podstawie haftowanego fragmentu brzegu halki. Wykonał wzorniki wespół z hafciarkami - Martą Pierzyńską ze Złotowa i Celiną Bytkowską z Krajenki (Niedżwiecki 1977a: 120; 1977b: 38)5. Wzorniki miały postać szkiców ołówkowych, gotowych haftów poglądowych i wycinanek (te ostatnie wykonała Marta Pierzyńska). Wzorniki przedstawiają motywy i kompozycje historyczne oraz inne zaproponowane przez Niedżwieckiego i wymienione hafciarki. Szkice, wycinanki i część prac haftowanych znajdują się w archiwum muzeum złotowskiego. Za pośrednictwem Niedżwieckiego i współpracujących

\footnotetext{
${ }^{4}$ Odtworzenie społeczno-kulturowych warunków powstania tego haftu przypadającego na pierwszą ćwierć XX wieku wiąże się z kilkoma przeszkodami: po pierwsze hafciarki ze Starej Świętej, które zaprojektowały ten haft w pierwszej połowie XX wieku opierając się na powszechnie występujących na Krajnie kaszubskich wzorach szkoły wdzydzkiej już nie żyją, a wspomnienia członków ich rodzin są szczątkowe. Po drugie Złotów należał do końca drugiej wojny światowej do państwa pruskiego, które planowo niszczyło przejawy polskości i w związku z tym nie prowadzono w Niemczech dokumentacji etnograficznej polskiej kultury ludowej. Po trzecie Oskar Kolberg, największy dokumentalista XIX wieku, choć przemierzał ziemie dawnej Rzeczpospolitej, nie wykonał badań w dawnym zaborze pruskim, a więc na Krajnie Złotowskiej, poza Wielkim Księstwem Poznańskim, do którego należała tylko Krajna Nakielska.

${ }^{5}$ Trudny do oceny jest wkład pracy innych członkiń złotowskiego koła hafciarskiego (dziś już nieistniejącego), ponieważ żyje jeszcze tylko jedna osoba z tego grona, Irena Bielecka, której kondycja zdrowotna obecnie nie pozwala na udzielenie wywiadu.
} 


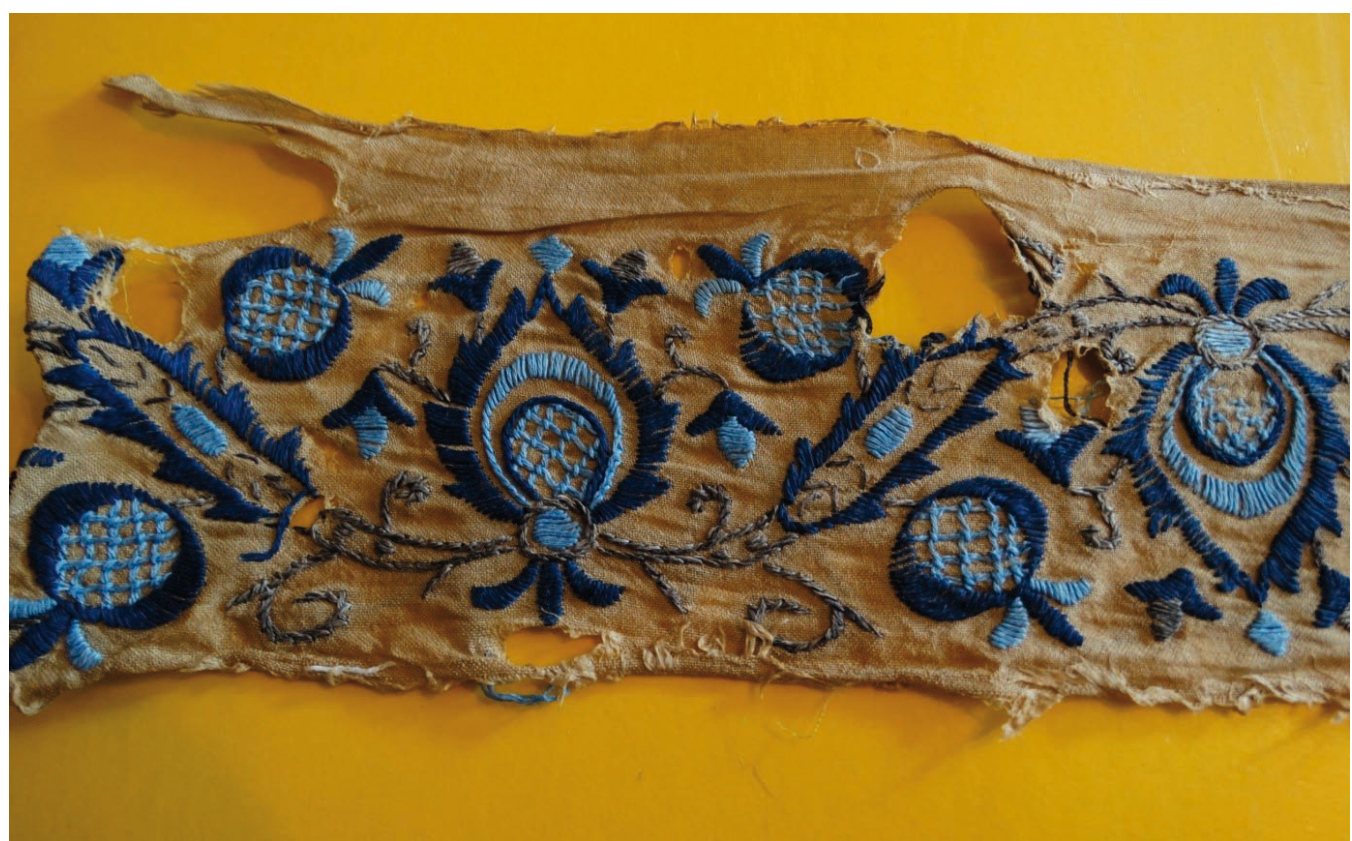

Fot. 1. Zachowany najstarszy fragment brzegu haftowanej halki ze Skica z 1910 roku. Ze zbiorów Muzeum Ziemi Złotowskiej w Złotowie (fot. D. Angutek).

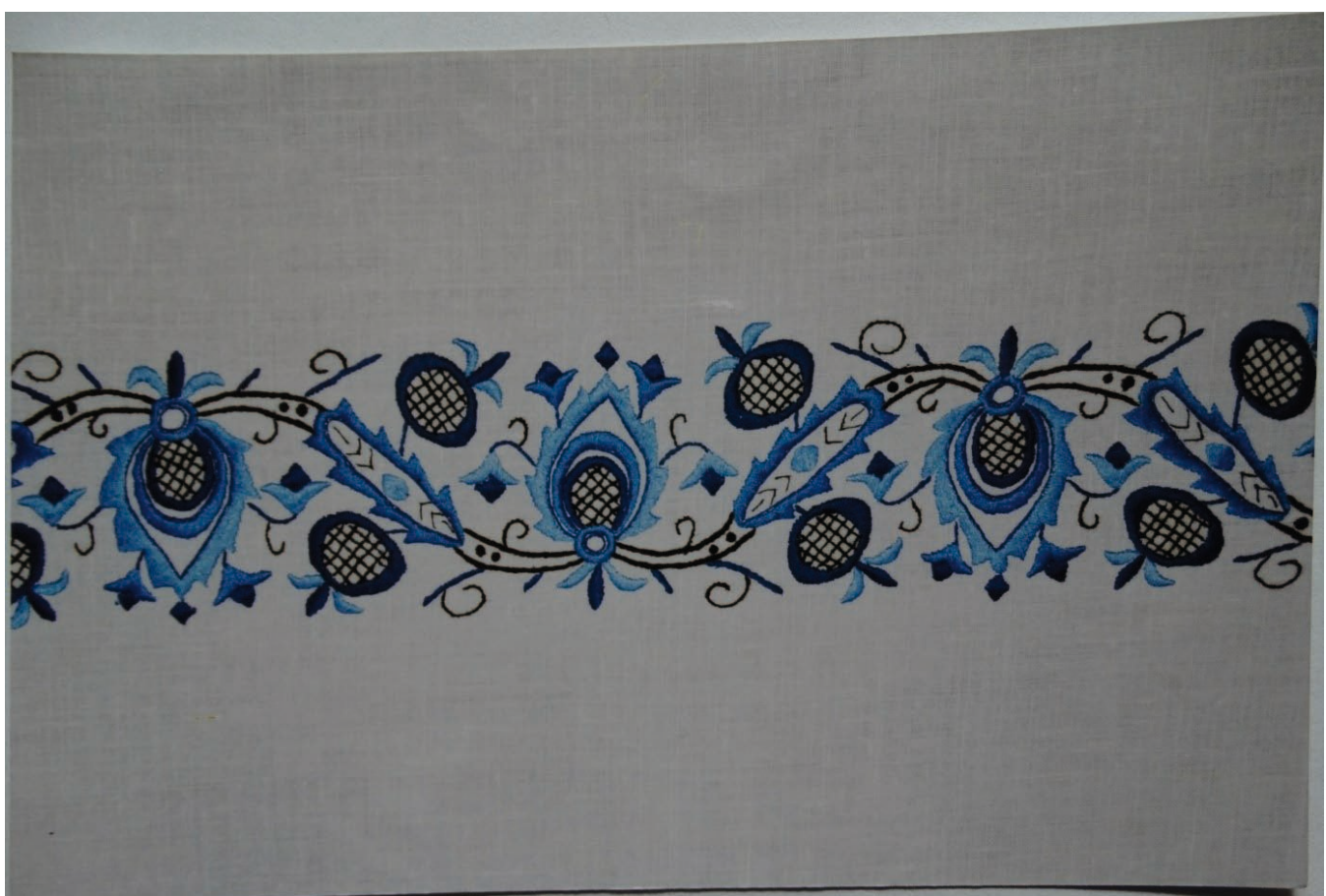

Fot. 2. Replika z 2000 roku wzoru z halki przedstawionej na Fot. 1. Wyk. Irena Cichończyk. Własność Piotr Pankanin z Więcborka (fot. D. Angutek). 


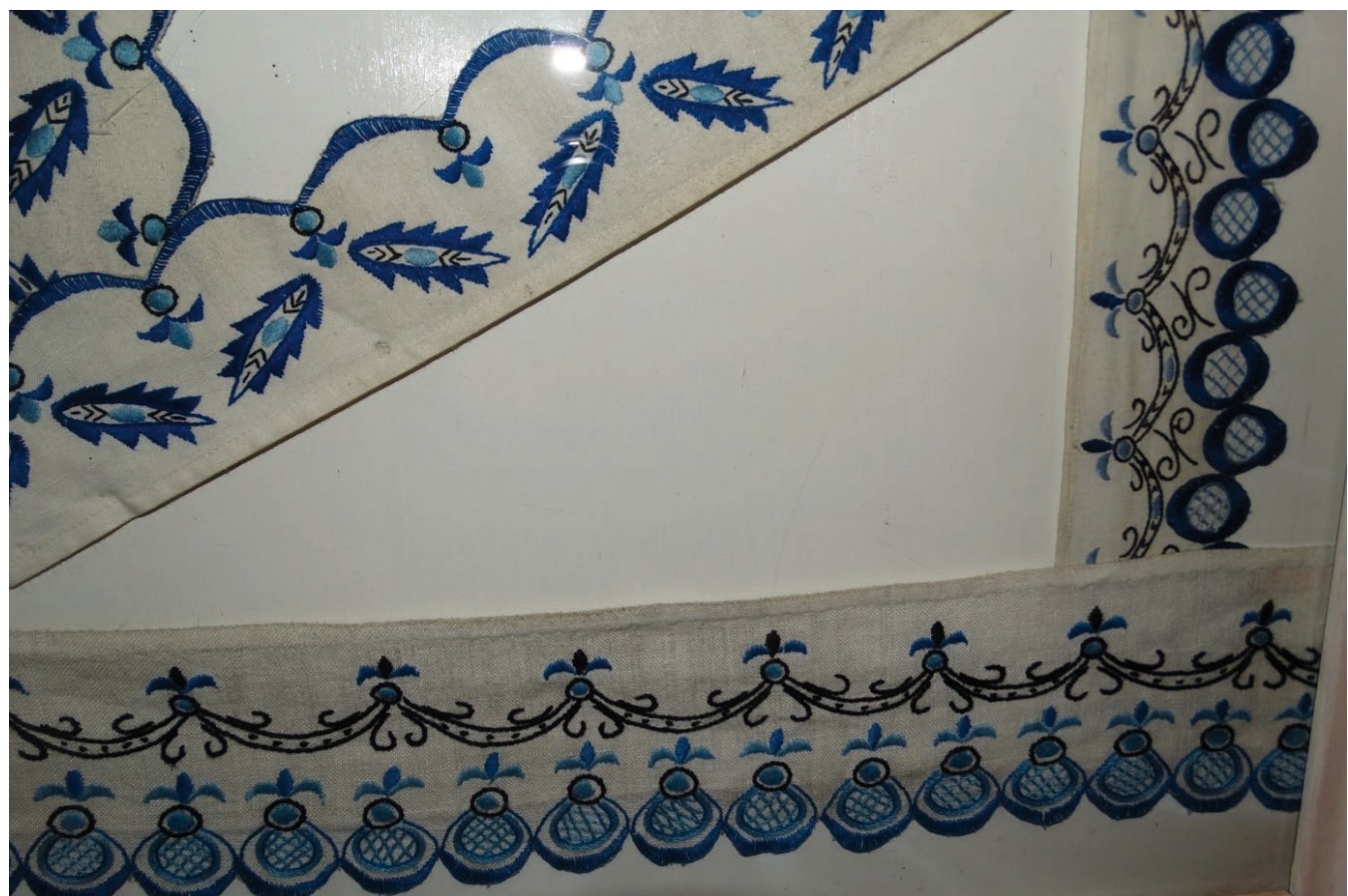

Fot. 3. Haftowana listwa (kajnt) z 1920 roku. Wyk. Elżbieta Massel ze Świętej. Ze zbiorów Muzeum Ziemi Złotowskiej (fot. Zofia Korpusik-Jelonek).

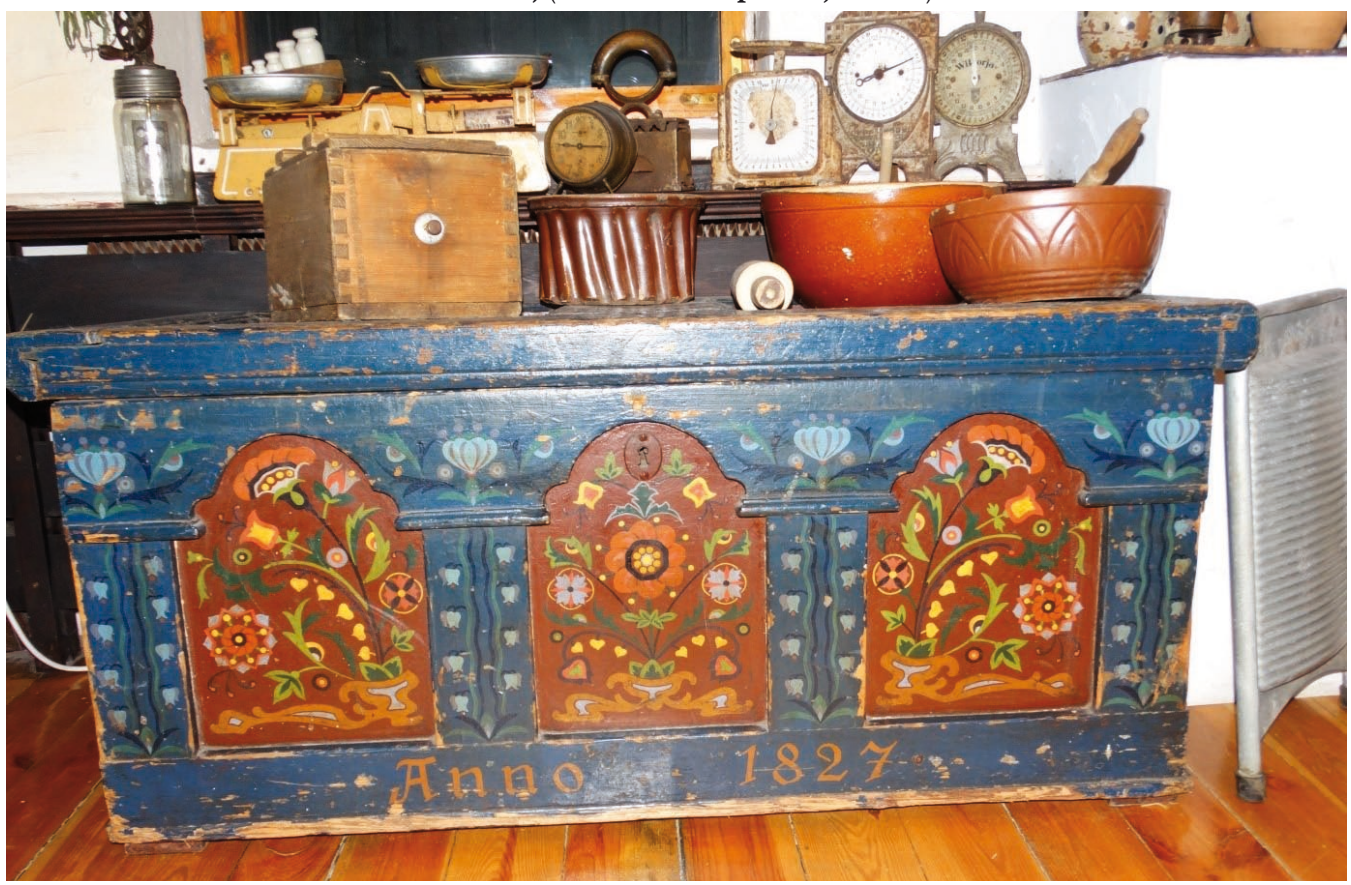

Fot. 4. Skrzynia posażna z okolic Nakła z 1827 roku z malaturą o cechach dziewiętnastowiecznego zdobnictwa kaszubskiego. Ze zbiorów Muzeum Ziemi Krajeńskiej w Nakle n/Notecią (fot. D. Angutek). 
z nim pań upowszechnił się haft w powiatach złotowskim i pilskim. Nie ekspandował on w latach 70. XX wieku na inne obszary Krajny. Etnograficzne działania Niedżwieckiego w celu pozyskania eksponatów historycznych przedstawiających haft ze Starej Świętej i ze Skica należy określić jako poszukiwawczo-inwentaryzacyjne. Natomiast kolejny etap na drodze odtwarzania tego haftu wiązał się z działalnością złotowskiego środowiska. Niedżwiecki i hafciarki skupili się na wiernym odtworzeniu i przywróceniu do praktyki hafciarskiej ludowego haftu krajeńskiego (złotowskiego). Można nazwać ten etap rekonstrukcyjnym.

Następnie toruńska muzeolog i etnograf, Halina Mikułowska, przeniosła wzory z historycznych eksponatów haftowanych znajdujących się w Złotowie na elementy rekonstruowanego przez nią stylizowanego stroju krajeńskiego. Prace prowadzone pod jej kierunkiem odpowiadały na potrzeby zespołu śpiewaczo-tanecznego działającego przy Miejsko-Gminnym Ośrodku Kultury (MGOK) w Kamieniu Krajeńskim. Przez porównanie wzorów haftów znajdujących się w muzeum złotowskim oraz tych umieszczonych na strojach z Kamienia wnioskuję, że uboższe hafty na bluzkach i koszulach męskich zostały przeniesione głównie z kajntu ${ }^{6}$ (Fot. 3), natomiast białe ornamenty haftowane na tiulowych fartuszkach zostały replikowane $\mathrm{z}$ fragmentu halki (Fot. 1). Mikułowska dokonała świadomego przeniesienia oryginalnych motywów haftu złotowskiego na tereny, gdzie prawdopodobnie nigdy on nie występował, czyli na Krajnę Nakielską. Zapewne jej celem nie było zainicjowanie dyfuzji tego haftu, lecz wykonanie możliwie najwierniejszej repliki stroju opartego na istniejących źródłach archiwalnych, a te znajdowały się tylko w Złotowie i Toruniu. Miało to miejsce w I połowie lat 80 . XX wieku. Jednak z Kamienia animatorzy-amatorzy zaczerpnęli (wybiórczo) wzory dla innych krajeńskich zespołów śpiewaczo-tanecznych z Lutowa k. Sępólna i Sadek k. Nakła. Ten etap upowszechniania się haftu na Krajnie, kiedy amatorsko wykorzystano rekonstrukcje Mikułowskiej, można nazwać popularyzującym.

Badaczki amatorki z Więcborka: Jadwiga Domańska i Zofia Cybulska oraz Wanda Kindowa upowszechniły na Krajnie Nakielskiej haft ze Starej Świętej ${ }^{7}$ w ramach aktywności w Kole Hafciarskim „Igłą Malowane”. Na przełomie 1979 i 1980 r. ubiegłego wieku z własnej inicjatywy rozpoczęły poszukiwania wzorów haftu krajeńskiego

\footnotetext{
${ }^{6} \mathrm{~W}$ gwarach ludowych „kajntem” nazywano ozdobną listwę z materiału przytwierdzaną do ram miśników, tzn. „regałów”, w których wystawiano talerze wykonane z porcelany, zwłaszcza miśnieńskiej, w celach estetycznych i dla podkreślenia statusu majątkowego gospodarza.

${ }^{7}$ Dawna nazwa wsi Stara Święta w po drugiej wojnie światowej została zmieniona na Świętą.
} 
w muzeum złotowskim i w chacie ludowej w Starej Świętej (muzeum in situ). Właśnie tam ich uwagę zwrócił fragment brzegu halki z ręcznie wyszytym błękitno-granatowoczarnym haftem ${ }^{8}$ (Fot. 1). Postanowiły skopiować wzór ołówkiem, by po powrocie zająć się jego wykonaniem (Fot. 2). Polegało ono na rozbiciu haftu na motywy i kompozycje. Inicjatywa ta wypłynęła z ich potrzeby ożywienia czy wręcz stworzenia tradycji dla tego obszaru z okazji obchodów 600-lecia lokacji miasta Więcbork. Władze, a przede wszystkim środowiska skupione na kulturalnym życiu miasta, potrzebowały charakterystycznych emblematów z odległych czasów, które uwiarygodniłyby tożsamość kulturową tego wycinka regionu Krajny, a zarazem dały podstawę ożywieniu działalności kulturalnej. Był to kolejny etap replikowania i upowszechniania haftu krajeńskiego. Hafciarki z Więcborka stały się inicjatorkami tzw. tradycji wytworzonej (Hobsbawm 2008: 9-19), która polega m.in. na zapożyczaniu tradycji z innych obszarów i przyjęciu jej jako własnej w celach integracyjnych i afiliacyjnych przez społeczności, które w tej mierze wykazują deficyt. W następnych latach znanymi popularyzatorkami haftu krajeńskiego w całym regionie i na sąsiednich terenach były Jadwiga Angutek, Aleksandra Banach, Irena Cichończyk, Kazimiera Chyła, Halina Krakowska, Teresa Kuczerepa, Janina Sołtysiak, wszystkie z Więcborka. Co ciekawe, a podnoszące wiarygodność i rzetelność hafciarek z Więcborka, mimo że grupy z Więcborka i ze Złotowa nie wiedziały o swoim istnieniu, stworzyły niezależnie identyczne wzorniki, opierając się na tych samych wzorach historycznych haftów ludowych.

Podsumowując, to w okolicach Złotowa powstał haft krajeński, po którym zachowały się do dziś zaledwie trzy eksponaty historyczne świadczące o jego istnieniu. To w Świętej (licząc eksponat ze Skica umieszczony w chacie krajeńskiej w Świętej) pojawiły się trzy „ogniwa” dyspersji przestrzennej, za pośrednictwem których haft ten rozprzestrzenił się w ostatnich czterdziestu latach na całą Krajnę.

\section{Kaszubskie pochodzenie haftu krajeńskiego i jego przekształcenie na Krajnie}

Na początku powtórzę tezę Niedżwieckiego głoszącą, że ludowy haft krajeński z okolic Złotowa wywodzi się z haftu kaszubskiego, o czym świadczą występujące w obu

\footnotetext{
${ }^{8}$ Hafciarki nie potrafiły odgadnąć funkcji użytkowej fragmentu tkaniny i nazwały ów brzeg halki „krajką”.
} 
gałęziach tego rzemiosła identyczne motywy i podobny sposób ich stylizacji ${ }^{9}$. Tak więc haft kaszubski i krajeński są genetycznie powiązane ze sobą. Choćby tylko na podstawie zauważalnych podobieństw formalnych nasuwa się wniosek o wywodzeniu się haftu złotowskiego $\mathrm{z}$ kaszubskiego. Jednak twórca (projektant) czy twórcy kanonu ze Złotowa i jego okolic nadal pozostają nieznani. Przeprowadzona kwerenda źródeł pisanych nie wnosi żadnej informacji ani o istnieniu „szkoły złotowskiej”, ani o przenikaniu wzorów kaszubskich na Krajnę, choć jest to fakt niezbity ${ }^{10}$. Skupię się zatem na formalnych podobieństwach haftów obu regionów.

Obecne w hafcie ze Skica i Starej Świętej motywy granatu, dzwonków, makówek i lilii mają odległą historię południowo- i zachodnioeuropejską oraz kaszubską zainicjowaną przez Teodorę Gulgowską (z domu Fethke). Inspiracje prawdopodobnie płynęły z Kaszub Zachodnich, głównie z Bytowa, gdzie Gulgowska niejednokrotnie prowadziła warsztaty hafciarskie (Błachowski 2007: 218-220).Albo też, co raczej wydaje się wątpliwe, wzorowano się spontanicznie na kaszubskich haftach szkoły wdzydzkiej, które były powszechne na całej Krajnie i na ich bazie wykształcił się wzór złotowskiego haftu krajeńskiego. Zgromadzone w muzeach krajeńskich artefakty, takie jak malowane skrzynie posażne (Fot. 4), ornaty oraz chorągwie z I połowy XIX wieku i późniejsze wykazują formalne i genetyczne związki ze zdobnictwem kaszubskim jeszcze przed jego ujednoliceniem dokonanym za sprawą Gulgowskich i Majkowskich.

Przyjmujęjednak bardziej prawdopodobną hipotezę o wpływie haftu opracowanego przez Gulgowską na haft złotowski za pośrednictwem nieznanego nam z nazwiska animatora współpracującego z Gulgowską. Zapożyczono wybrane motywy (tematy) $\mathrm{z}$ haftu wdzydzkiego: owoce granatu, liście dębu (przekształcone na Krajnie w kłosy zboża), makówki, lilie i dzwonki, a następnie przekształcono je stylistycznie. Rozwój pewnych praktyk kulturowych szczególnie tam, gdzie zagęszczenie ludności jest dość duże, a ludność łączą ekonomiczne więzi, sprzyja przenikaniu i spontanicznej wymianie lub jednostronnemu zapożyczaniu wzorów kulturowych.

${ }^{9}$ Identyczną sugestię wysunęła pani Kinga Skowronek-Turska, starszy kustosz w Muzeum Etnograficznym im. M. Znamierowskiej-Prufferowej w Toruniu. Była ona pierwszą osobą, która wprowadziła mnie w zagadnienia powiązane $\mathrm{z}$ haftem kaszubskim i zachęciła do badań nad nieuznanym do dziś haftem złotowskim (przy czym nie rozstrzygała na rzecz żadnej ze stron sporu wokół haftu krajeńskiego). Pragnę podziękować jej za wieloletnie wspieranie mnie fachową wiedzą, którą wykorzystałam w przedsięwzięciu, którego skromnym uwieńczeniem jest niniejszy artykuł.

${ }^{10}$ Bardzo dziękuję Pani Bogumile Szopie-Strzelczyk, starszej kustosz w Bibliotece Naukowej PTPN w Poznaniu za dobrowolne i bardzo dokładne wykonanie kwerendy źródeł pisanych na temat haftu i stroju krajeńskiego oraz kaszubskiego. 
Za oficjalną datę upowszechnienia ludowego haftu kaszubskiego uznaję, za Aleksandrem Błachowskim, rok 1906. Wtedy Gulgowscy zorganizowali we Wdzydzach pierwszy kurs hafciarski (Błachowski 2007: 218-219). Istnieje wspomnienie Gulgowskiego o zaprzyjaźnionej pisarce niemieckiej Marii Heller, która popularyzowała osiągnięcia Gulgowskich i prace hafciarek z Wdzydz na łamach czasopisma „Daheim” w 1907 r. i „Kolnischen Volkscheitung” w roku 1908 (Gulgowski 2012:148). Stąd wnioskuję, że po 1906 r. haft złotowski mógł wyewoluować $\mathrm{z}$ haftu wdzydzkiego za przyczyną bliżej nam nieznanego projektanta. Rok 1909 okazał się decydujący dla dalszego rozwoju haftu kaszubskiego. Wówczas to Teodora Gulgowska wraz ze swym mężem Izydorem Gulgowskim na wystawach w Berlinie, a następnie w Kaliszu, przedstawiła haftowane tkaniny użytkowe pokryte stylizowanymi artystycznie, głównie dekoracyjnie, kaszubskimi wzorami (Majkowski 1909: 126; Graeve i in. 1909: 1; Dzikowski 1909: 13).

Zgodnie z tendencją panującą w tamtych czasach, artyści zaangażowani w amatorski ruch ludoznawczy organizowali warsztaty rękodzieła artystycznego dla ludności wiejskiej. Ci profesjonalni artyści-plastycy zajmowali się tworzeniem wzornictwa "ludowego" dla chłopów polskich w kowalstwie, snycerce, architekturze, malarstwie, stroju i wreszcie hafcie. Zawsze brali za kanwę istniejące tendencje regionalne i dążyli do ujednolicenia istniejących wariantów motywów i wzorów. Posiłkowali się przy tym wiedzą profesjonalną z zakresu reprezentowanej przez siebie dziedziny sztuki wysokiej (Błachowski 2007: 202-214; Gulgowski 2012: 146-147). W ten sposób z udziałem profesjonalnych artystów-ludoznawców powstawały wzory, których chętnie się uczono - dawało to bowiem możliwości dodatkowego zarobkowania, a w przypadku bardzo ubogich panien szanse na utrzymanie i zdobycie tą drogą dobrze widzianego posagu, czego świadomi byli Gulgowscy (Gulgowski 2012: 147-151).

W hafcie kaszubskim występują elementy zupełnie obce pierwotnym tendencjom ludowym, np. rozety, które były ulubionym motywem Gulgowskiej, czy owoc granatu. Motyw ten pojawia się także w hafcie krajeńskim i sięga korzeniami do białego haftu bielizny ołtarzowej wykonywanej najpierw tylko na potrzeby kościołów (Fot. 5).

$\mathrm{Z}$ czasem autonomicznie potraktowany motyw granatu stał się centralnym motywem kobiecych czepców haftowanych złotą nicią (złotnice zwane także złotogłowami), noszonych przez bogate zamężne szlachcianki z Kaszub (Fot. 6, 7, 8). Gulgowska przeniosła następnie ten motyw ze złotnic do haftu ludowego na kaszubskiej odzieży i tkaninach użytkowych (Fot. 6, 7), stylizując go na motyw ludowy 


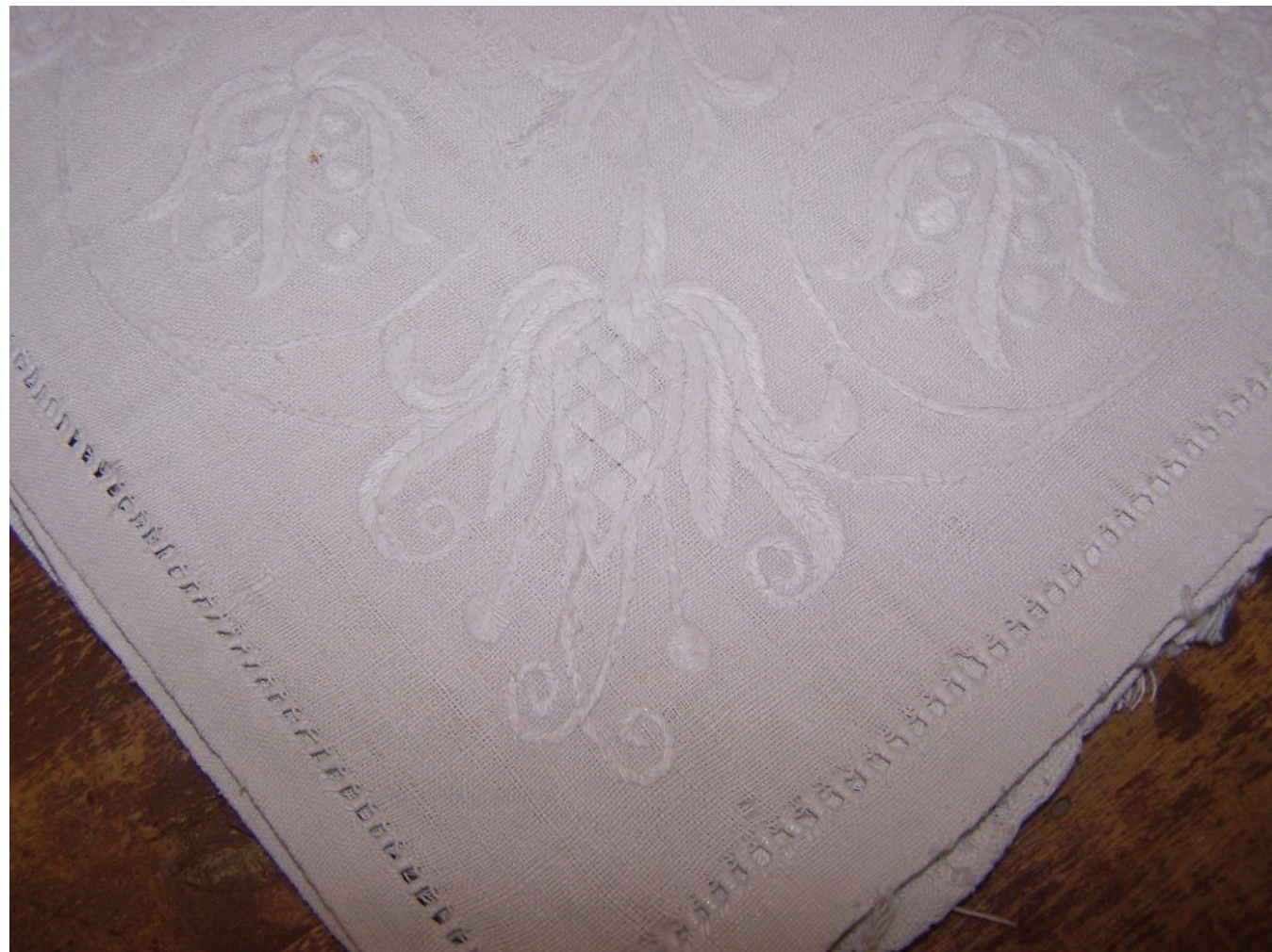

Fot. 5. Fragment antepedium nakrycia ołtarza z Żukowa z 1746 roku przedstawiający stylizowany owoc granatu. Ze zbiorów Muzeum Etnograficznego w Gdańsku-Oliwie (fot. D. Angutek).

o bogatej, kontrastującej kolorystyce (Gulgowski 1912: 145). Stamtąd zaś, w sposób nieustalony jeszcze przeze mnie, przeniesiono ten motyw na Krajnę. Stanowi on główny motyw zdobniczy haftu krajeńskiego. Towarzyszą mu wspomniane główki makówek, kłos zboża, drobne lilie i dzwonki wraz z nasionami i łącznikami (łodygi i czepy, tzw. wąsy), co obrazuje fotografia nr 8. Do ustalenia pozostaje źródło i ewentualna forma wzornicza, którą hafciarki krajeńskie wykorzystały jako podstawę przy wykonywaniu listwy zachowanego fragmentu halki. Prawdopodobnie układ motywów pochodzi z paramentów kościelnych. Na identyczną kompozycję natknęłam się w katalogu z wystawy w Olsztynie z 1955 r., w którym widnieje fotografia skraju halki (Fot. 1.) z powiatu pasłęckiego, ozdobionego haftem białym z podobnymi motywami, jak na fotografii nr 1 (Judziewicz i in. 1955). Wiadomo zaś, że tereny na wschodnim brzegu Wisły także podlegały wpływom kaszubskim i oddziaływaniu wzornictwa kościelnego i kaszubskiego. 

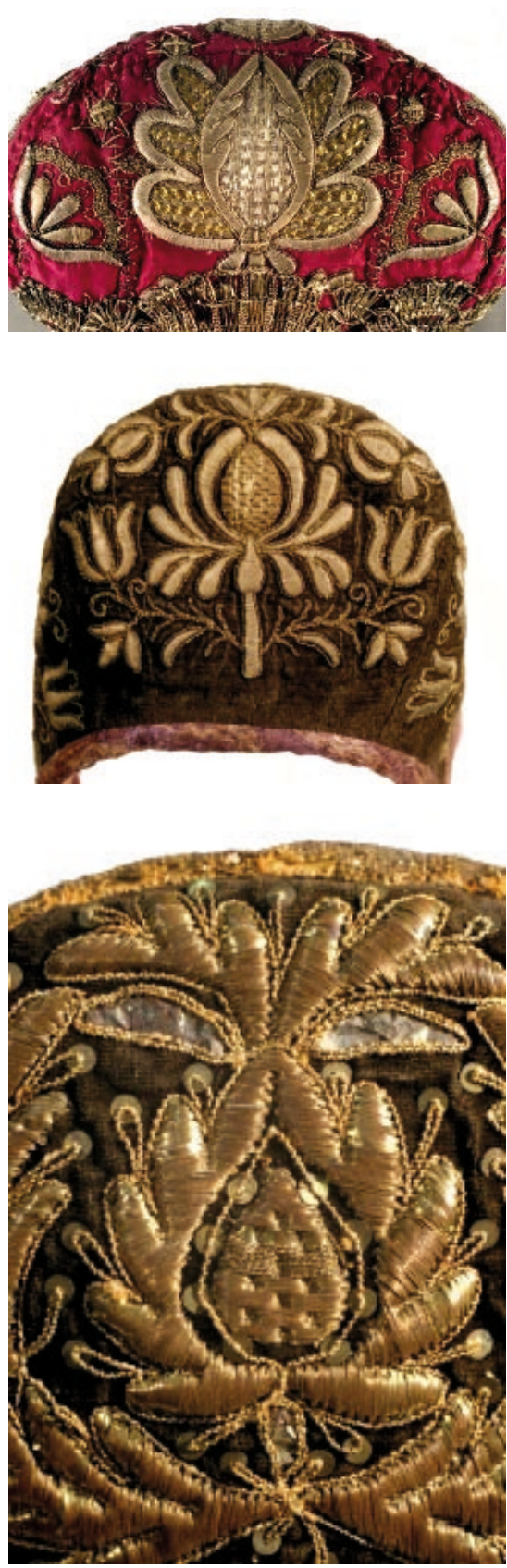

Fot. 6, 7, 8. Złotnice kaszubskie z XIX wieku $\mathrm{z}$ widocznym centralnie umieszczonym motywem owocu granatu. Ze zbiorów Muzeum Etnograficznego w Toruniu (fot. M. Kosicki).

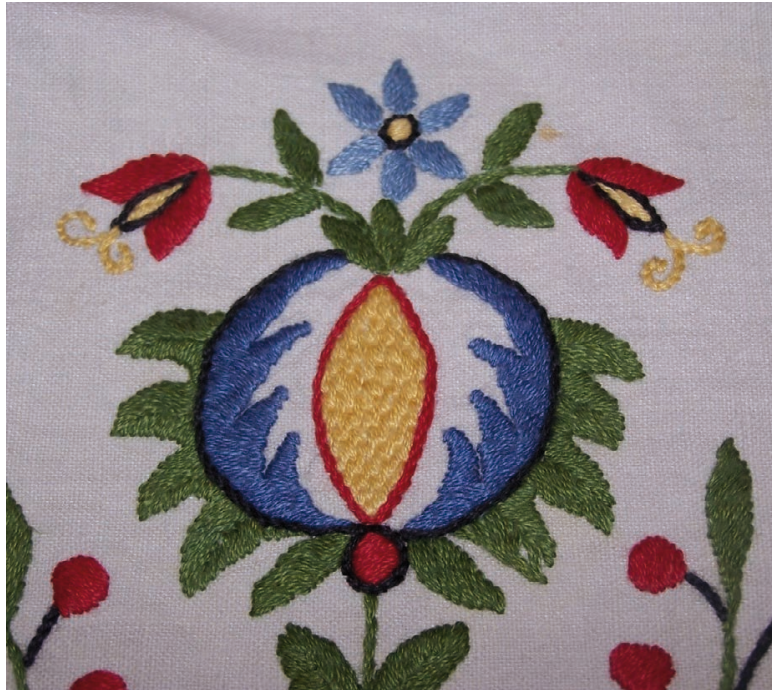

Fot. 9. Motyw owocu granatu w hafcie szkoły wejherowskiej. Ze zbiorów Muzeum Etnograficznego w GdańskuOliwie (fot. D. Angutek).

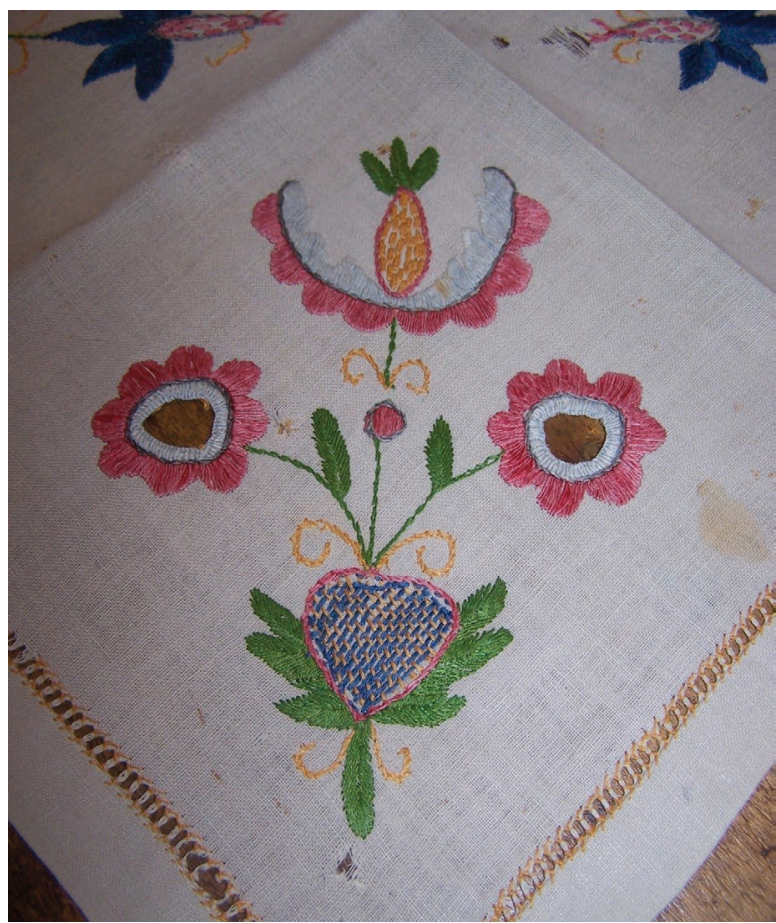

Fot. 10. Motyw owocu granatu na serwetce ze szkoły wdzydzkiej. Ze zbiorów Muzeum Etnograficznego Gdańsku-Oliwie (fot. D. Angutek). 


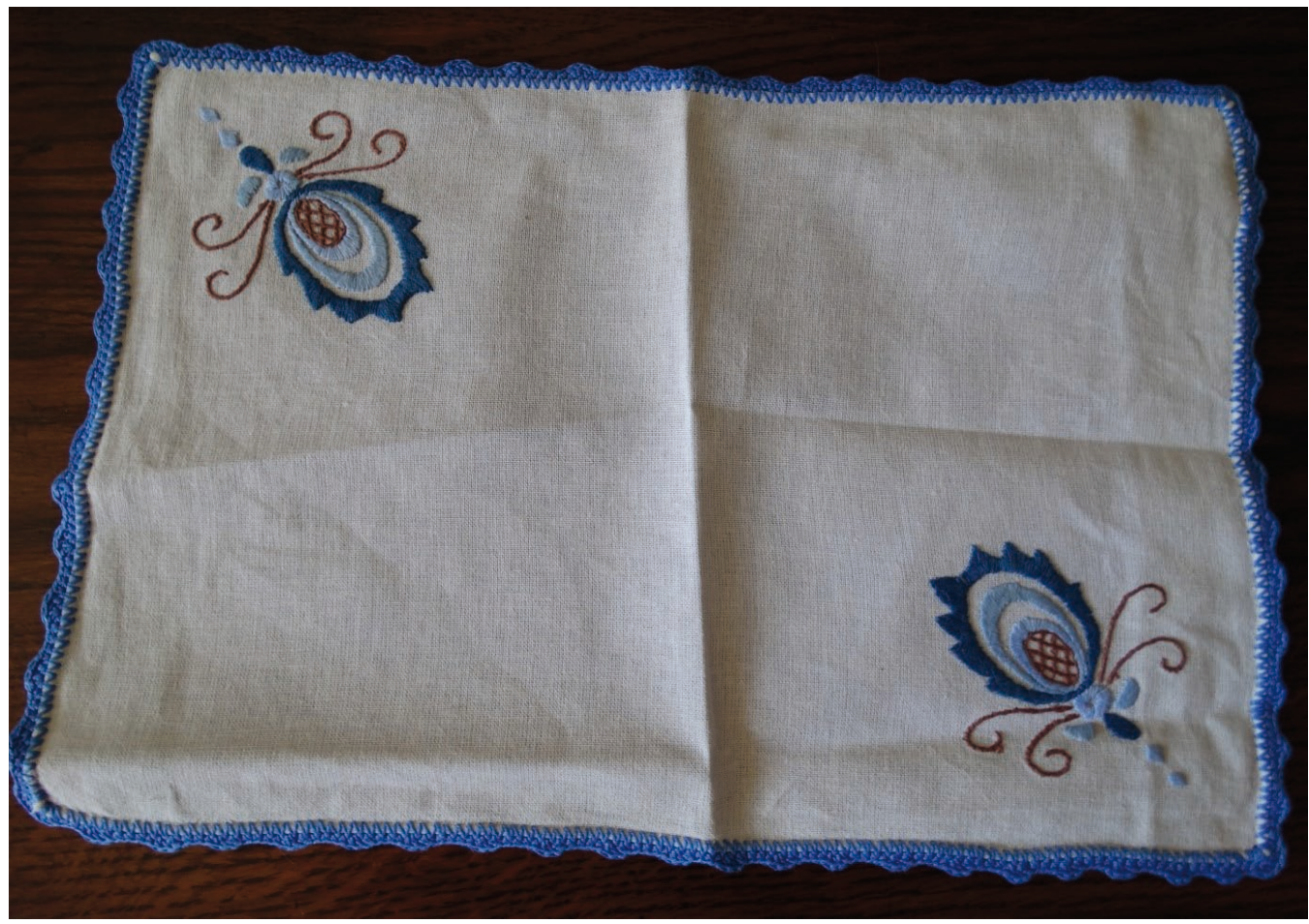

Fot. 11. Przybliżona rekonstrukcja (błędnie zastosowano brązowy kolor zamiast czarnego) zaginionej serwetki z 1932 roku, pierwotnie znajdującej się w zbiorach Muzeum Ziemi Złotowskiej. Wyk. Jadwiga Angutek w 1997 roku. Z prywatnych zbiorów D. Angutek (fot. D. Angutek).

Datowanie haftów historycznych z okolic Złotowa przypada na lata od 1910 do 1932. Niestety zaginęła z Muzeum w Złotowie serwetka z 1932 r., która ozdobiona była dwoma identycznymi motywami owocu granatu (Fot. 11 przedstawia jej współczesną przybliżoną rekonstrukcję wykonaną z pamięci).

Natomiast, na fotografii kajntu (Fot. 3) widoczny jest wyeksponowany motyw kłosów z nasionami i plewami, których podstawy kielicha połączone są niewielkimi liliami albo dzwonkami, zakończonymi kółkiem z konturem. Zauważalny jest brak „wąsów” typowych w hafcie umieszczonym na halce.

Wszystkie trzy prace zostały wykonane prze różne osoby, o czym świadczą zapisy w księdze inwentarzowej i sposób wykonania tych prac. Fakt ten przemawia na rzecz tezy, że haft krajeński - jako osobna szkoła haftu kaszubskiego lub jego pochodna - utrwalił się jako styl hafciarski typowy dla okolic Złotowa (Fot. 11.).

Ponadto, fotografia $\mathrm{nr} 12$ przedstawia fragment serwety $\mathrm{z}$ haftem szkoły wejherowskiej(Fot. 12), który zawiera wymienione trzy motywy (liść dębu, lilia i makówka) oraz motyw owocu granatu (zob. też Fot. 9). Poza tym widoczny jest motyw serca 


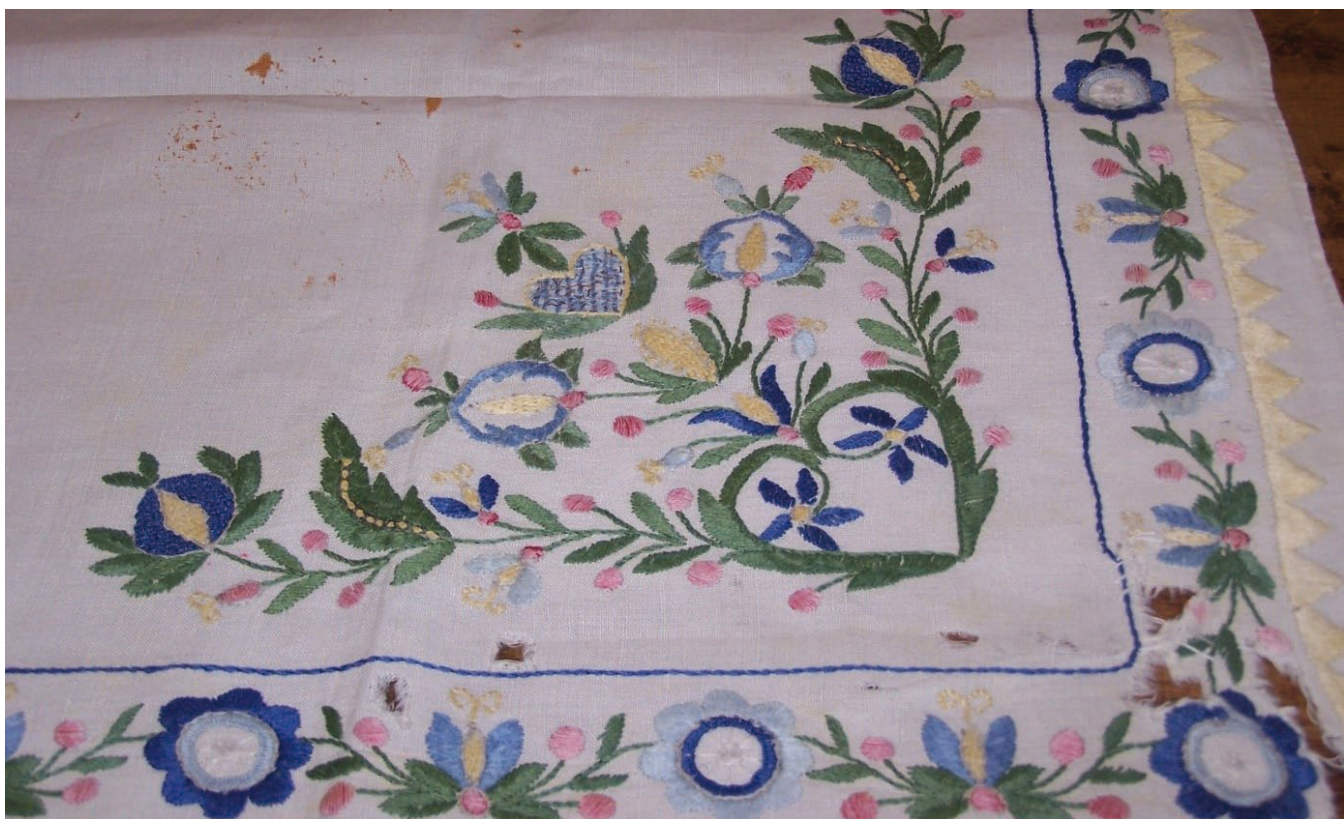

Fot. 12. Haft kaszubski szkoły wejherowskiej z początku XX wieku ze zbiorów Muzeum Etnograficznego w Gdańsku-Oliwie. Oprócz motywu granatu i serca, widoczna jest prefiguracja makówek. Liście dębu przekształcone zostały na Krajnie w kłos zboża (fot. D. Angutek).

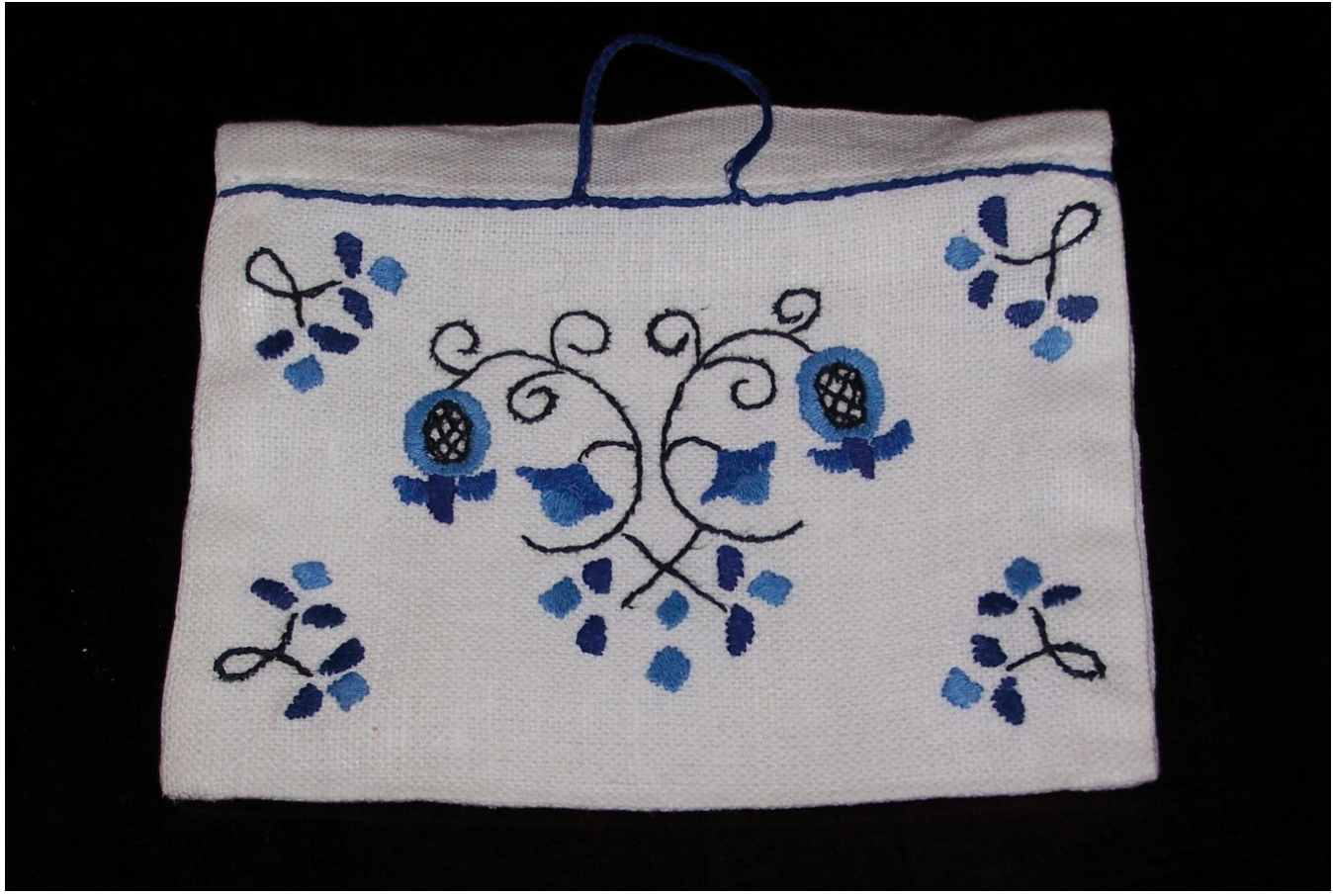

Fot. 13. Współczesna saszetka zapachowa do przechowywania ziół z widocznymi dwoma sposobami wykonania motywu lilii (motyw zgeometryzowany) i z dwoma dzwonkami. Wyk. Jadwiga Angutek z Więcborka w 1992 roku. Z prywatnych zbiorów D. Angutek (fot. D. Angutek). 
i stylizowanych okrągłych koszyczków kwiatów umieszczonych na obrąbieniu, które nie występują w hafcie złotowskim. Obecność trzech motywów wspólnych dla obu odmian haftu świadczy o wzajemnych związkach haftu kaszubskiego $\mathrm{z}$ haftem złotowskim.

Do zagadnienia genezy haftu ludowego z Krajny Złotowskiej należy również dobór motywów. Stawiam następującą hipotezę. Występujące w hafcie krajeńskim motywy powinny być traktowane jako integralny wyraz przekonań właściwych mentalności chłopskiej: kult maryjny i wynikające z niego wartości, wiara w opiekę Matki Boskiej nad zajęciami rolniczymi. Omówionych motywów nie należy traktować autonomicznie i odczytywać ich symbolicznego znaczenia w oderwaniu od wymowy całej kompozycji i możliwych jej konfiguracji. Przemawia za tym zarówno (1) historyczna jednoczesność ich pojawienia się, jak i (2) światopoglądowa komplementarność sensów poszczególnych motywów z chłopskim kultem maryjnym i agrarnym. Wprawdzie w hafcie kaszubskim motywy były dobrane przez Gulgowską tylko pod względem estetycznym, a nie semantycznym, to na Krajnie uderza ich znaczeniowa wymowa i komplementarność tematyczna. Oszczędny dobór oraz konsekwentna powtarzalność motywów maryjnych i agrarnych jest specyficzną cechą haftu krajeńskiego. Należy ją rozpatrzeć w kontekście o wiele bogatszego wzornictwa na skrzyniach i haftach wdzydzkich. Mimo że ten styl był w powszechnym obiegu, nie został wykorzystany w przypadku omawianego haftu. Po trzecie pierwszymi wykonawczyniami tego haftu, jak wynika z badań pilotażowych i archiwalnych, były chłopki, a nie artysta-plastyk, który kierowałby się względami głównie estetycznymi.

Przeto uważam, że wybór, dobór i uszczuplenie motywów haftu wdzydzkiego i później powstałych szkół nastąpiły pod wpływem światopoglądu chłopskiego. W ornamencie tym zasadniczo znajdują się elementy nieprzypadkowe i niepozostające w związku ze społecznymi, kulturowymi i przyrodniczymi warunkami życia chłopa. Jeżeli weźmiemy pod uwagę fakt, że zaborca prowadził politykę germanizacyjną, a dodatkowo chłop uzależniony był od warunków klimatycznych, uzasadnione wydaje się dobrowolne poddanie się pod opiekę Matki Boskiej, której domeną było, m.in. nadprzyrodzone władanie zjawiskami przyrodniczymi wpływającymi na pracę chłopa. Maria jest więc patronką chłopa polskiego. Chłop zawsze łączył bogactwo plonów z jej opieką, mnożąc jej sanktuaria (Stomma 1986). Taka interpretacja roli Matki Boskiej jest tym bardziej prawdopodobna, że główne motywy haftu złotowskiego, tj. owoc granatu, makówki i lilie oraz dzwonki mają związek z kościelnym kultem maryjnym, 
a pozostałe $\mathrm{z}$ rolniczą aktywnością chłopa. W związku z tym warto wytłumaczyć symbolikę poszczególnych motywów w hafcie krajeńskim.

Owoc granatu. Potocznie, ale błędnie nazywany jest na Krajnie „tulipanem” w skutek naturalistycznych podobieństw do przekroju cebuli tulipana. Sy piące się z niego ziarna symbolizują miłość ofiarną i triumf wiecznego życia nad śmiercią (Forster 1990: 163-166). Takie objaśnienie nie przeczy komplementarnej interpretacji chrześcijańskiej, którą znajdujemy w pracy Kopalińskiego. Według niego owoc ten jest symbolem władzy i wielości cnót Matki Boskiej (Kopaliński 1990: 104).

Makówka. Symbolizuje przejściowość śmierci. Znaczenie to sięga do przedchrześcijańskiej wiary w rokroczne powracanie dusz zmarłych przodków do domostw, którymi się opiekowali. Spoczywając w ziemi, wpływali na plony i od nich mogła zależeć pomyślność w prowadzeniu gospodarstwa. Kult agrarny, choć związany z wiarą w Boga i świętych patronów pól, rzek, zwierząt domowych itd., zawierał także przekonanie o takim wpływie przodków. Śmierć dla dawnych chłopów to tylko okresowy spoczynek, sen właściwy duszom zmarłym, które zawsze mogły z niego powrócić. Mak oddawał ów synkretyzm wierzeniowy. Używano go zatem do przygotowywania zarówno potraw wieczerzy wigilijnej, jak i tych właściwych dla obchodów „dziadów”. Mam tu na myśli przede wszystkim rogale świętomarcińskie, dziedzictwo „dziadów” jesiennych - kiedyś było to jadło ofiarne w czasie żertw dla zmarłych ${ }^{11}$.

Lilie i kłosy zboża. Te pierwsze najczęściej stanowią symbol dziewiczej czystości Marii. Natomiast kłos to symbol zarówno paschalnego pokarmu, jak i zboża stanowiącego komponent podstawy żywieniowej chłopa polskiego.

Obecność motywu owocu granatu i dzwonków jest komplementarna z motywami roślin uprawnych - zboża i maków. Sensem wiążącym motywy roślinne z owocem granatu jest metafora cnót religijnych, cudownie wpływających na efekty prac agrarnych w postaci obfitości zbiorów zboża. Tak więc te trzy główne motywy: granat, kłos zboża i makówka są symbolami trzech najważniejszych i podstawowych sfer życia chłopstwa: religii, życia (żywności), śmierci (okresowego spoczynku przodków). Ogólnie tworzą one kolisty zamknięty symboliczny obieg pierwiastka ciągle odradzającego się życia w naszych warunkach klimatycznych. Tworzą więc ciąg Bóg - wegetacja - śmierć - odrodzenie. Te cztery korzenie ludzkiej egzystencji są symbolicznie zawarte w trzech głównych motywach haftu krajeńskiego: granatu,

\footnotetext{
${ }^{11}$ Jest to bardzo skomplikowane zagadnienie, na przedstawienie którego nie ma tu miejsca, ale jest ono wielokrotnie i szeroko omówione i udokumentowane w literaturze przedmiotu (Klinger 1931; Kossak 1958; Stomma 1981; Zadrożyńska 1986, 2000).
} 
kłosa zboża i makówki, a wsparte są dodatkowo drobniejszymi motywami kostki - rozsypanych ziaren i dzwonków, które można wiązać zarówno z symboliką mszalną, jak i apotropeicznym aspektem Marii jako istoty „niepokalanej”.

\section{Formalne cechy ludowego haftu krajeńskiego ${ }^{12}$}

Zanim zaczęto haftować na tkaninach o przeznaczeniu użytkowym i zarazem dekoracyjnym - serwetach, serwetkach, obrusach, narzutach, poduszkach itd. - najpierw haftowano odzież stroju ludowego (ta zasada obowiązywała w hafcie ludowym w XIX i na początku XX wieku). Należy przyjąć zatem, że zachowany fragment halki ze Skica (Fot. 1) jest najstarszym z zachowanych eksponatów muzealnych.

Główne motywy haftu krajeńskiego umieszczone na trzech zachowanych tkaninach wraz z ich domniemaną symboliką zostały już wymienione. Są to: „pęknięty” owoc granatu, makówka, kłos zboża, dzwonki i drobne lilie. Oprócz tego mamy "wąsy" i łączniki wykonane sznureczkiem, wypełnione stylizowanymi nasionami w postaci kwadratów i kółek. Ostatnim zaś motywem jest kółeczko wypełnione haftem płaskim niepodwlekanym. Stanowi ono podstawę owocu lub kwiatostanu. Przekrój motywów, co charakterystyczne dla tego haftu, jest wzdłużny. Omówię teraz formalne cechy wymienionych motywów i ich kompozycje w hafcie krajeńskim.

Owoc granatu. Motyw ten zawiera dwa ważne elementy, które wskazują, że wywodzi się z wzoru o symbolicznej, eschatologicznej wymowie, spotykanego w kościołach od czasu renesansu. Jeśli mu się przyjrzeć, zauważymy, że wnętrze owocu, w którym są gęsto skupione ziarna oraz okalające je dwie „łuski” czyli skóra owocu, oddają pęknięcie dojrzałego owocnika. Wskutek tego tworzą się w sumie dwie wewnętrzne krawędzie i dwie zewnętrzne krawędzie tej „łuski”, „torebki” czy inaczej skóry owocu. Właśnie sypkie, mnogie nasiona obrazowano w postaci siateczki, pierwotnie błękitnej, zwanej popularnie „kratką”. Owa siateczka powtarza się w motywie makówki. Utworzona przez krzyżujące się, luźno przewlekane nici wewnątrz motywu owocu granatu i makówki imituje ciasno skupione nasiona w gniazdach naturalnych owoców. Kolejną cechą stylizacji są okalające siateczkę trzy eliptyczne krążki przy pominające razem strukturę pawiego pióra, do którego

\footnotetext{
${ }^{12} \mathrm{Na}$ potrzeby naukowego wywodu dokonuję pewnej idealizacji ludowego wzoru haftu krajeńskiego jako kanonu zamkniętego. Zdaje sobie jednak sprawę, że w praktyce style w sztuce ludowej nigdy nie były „sztywne”, lecz podlegały indywidualnym przeróbkom i innowacjom (por. Jackowski 2007: 17-19).
} 


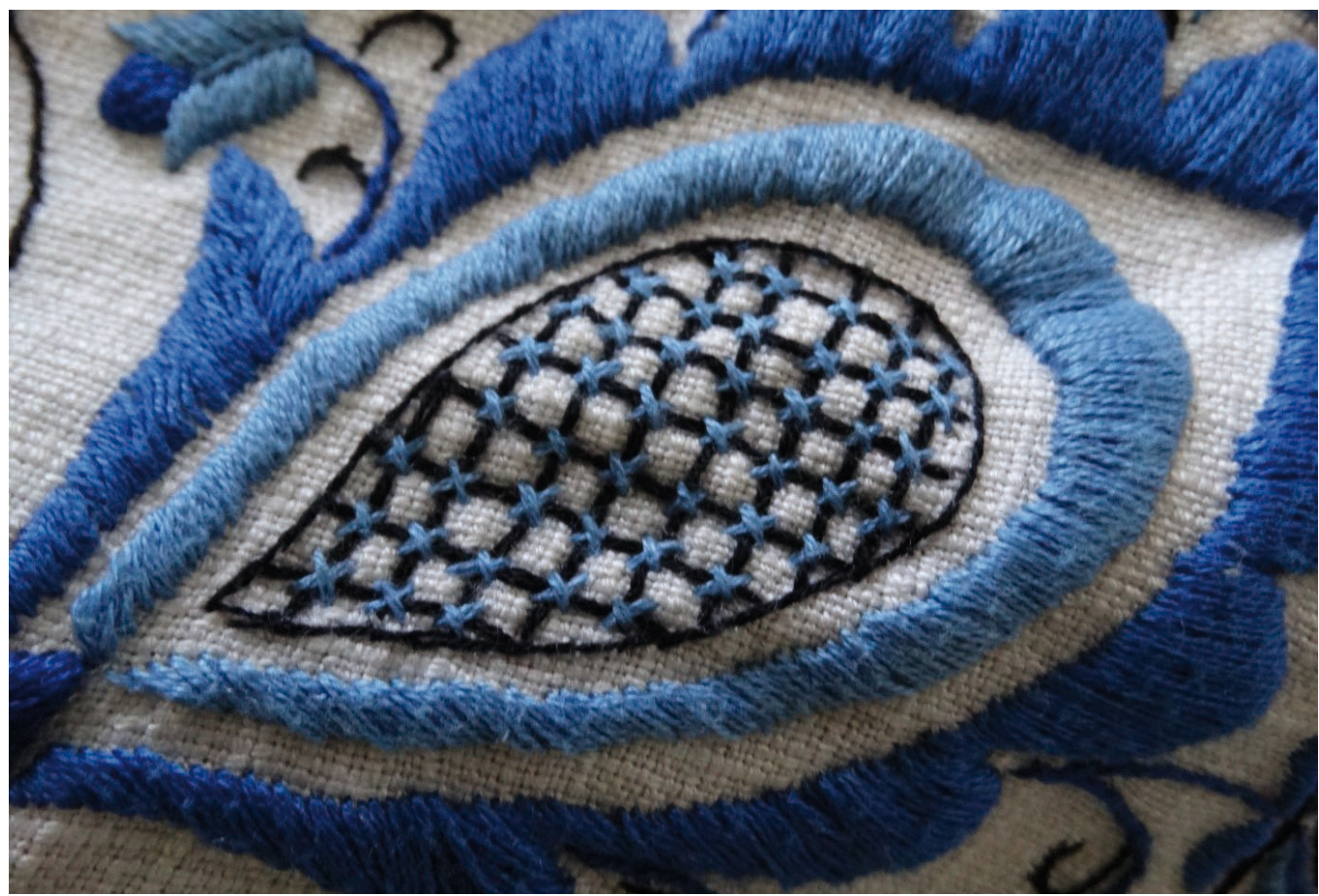

Fot. 14. Motyw owocu granatu z błędnie dodanymi krzyżykami. Tworzą je błękitne nitki przytwierdzające do płótna czarną siateczkę (imitacja ziaren). Właściciel anonimowy (fot D. Angutek).

potocznie bywa porównywany nieznany hafciarkom z nazwy motyw granatu. Natomiast ząbkowanie najbardziej zewnętrznej „obrączki” motywu pozostaje jeszcze do ustalenia, ale prawdopodobnie nawiązuje do już mocno stylizowanego motywu owocu granatu w haftach kaszubskich, który pierwotnie stanowił zielone rozchylone listki przekształcone w płomienie symbolizujące „żywą miłość”.

Makówka. Jest najłatwiejszym do odgadnięcia motywem, albowiem jego proporcje w stosunku do motywu owocu granatu przypominają proporcje naturalne, a wewnętrzna siateczka imitująca nasiona utwierdza nas w trafnym odczytaniu tej stylizacji.

Kłos zboża. Nie zachowuję umownej na terenie Więcborka nazwy „kłos trawy”. Można by dopatrywać się a nalogii z kwiatostanem trawy pod względem formalnym (podłużny kształt listków). Jednak podtrzymując tezę, że haft krajeński jest pokrewny haftowi kaszubskiemu, analogii należy poszukiwać na Kaszubach, a dopiero później w naturze. Otóż w hafcie kaszubskim pojawiają się właśnie małe podłużne listki, których wnętrze wypełniają drobne, regularnie ułożone, zazwyczaj okrągłe punkciki, co przypomina kłos zboża. W hafcie krajeńskim jako motyw podstawowy jest on znacznie bardziej uwydatniony i dekoracyjnie urozmaicony niż ma to 

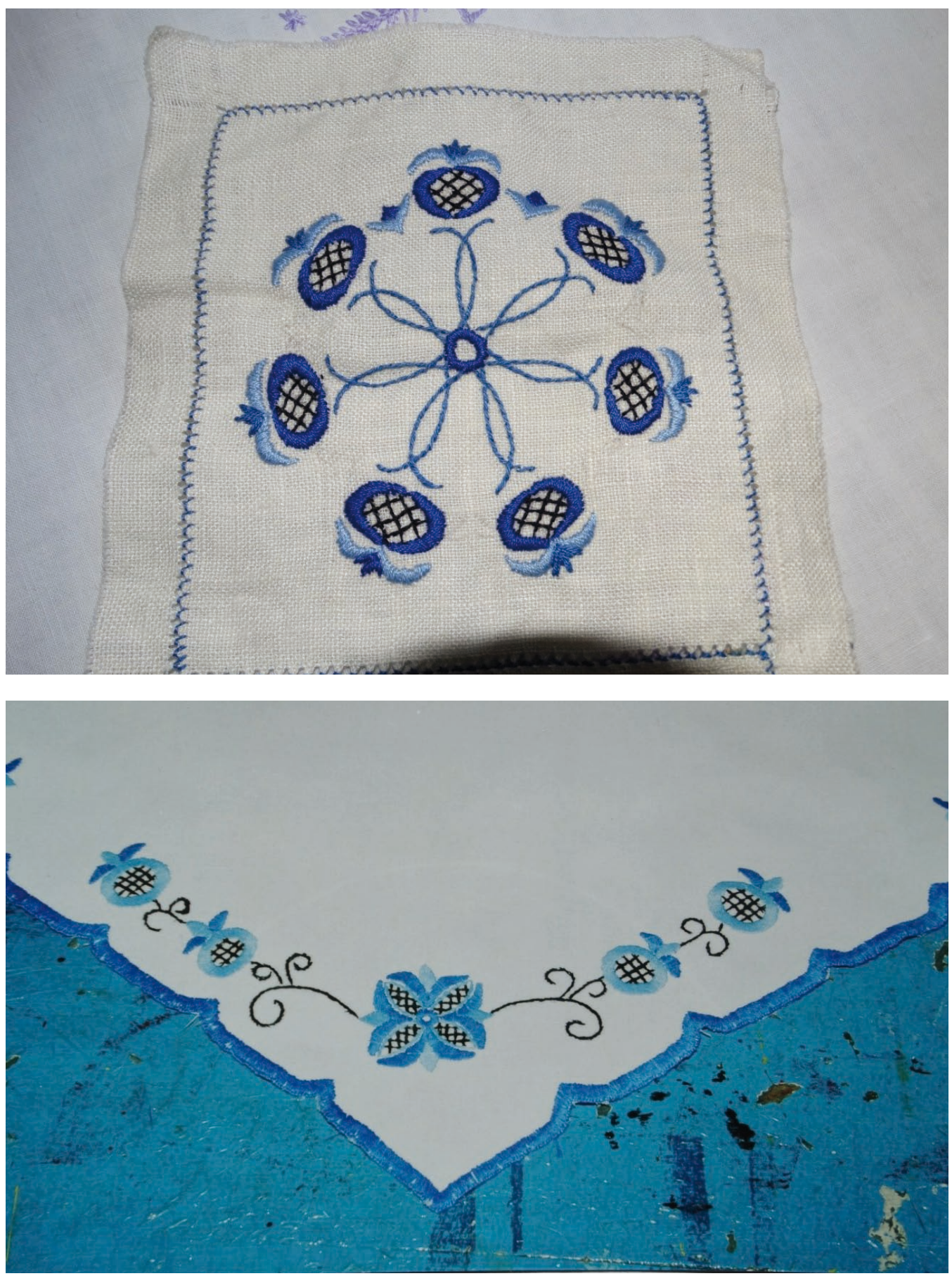

Fot. 15, 16. Dwa przykłady „niewłaściwych” kompozycji (wykonanych po 2000 roku) utworzonych z motywu makówki, które dają efekt nowego, odmiennego motywu od motywów opisanych jako kanoniczne. Właściciel anonimowy i MGOK w Więcborku (fot. D. Angutek). 


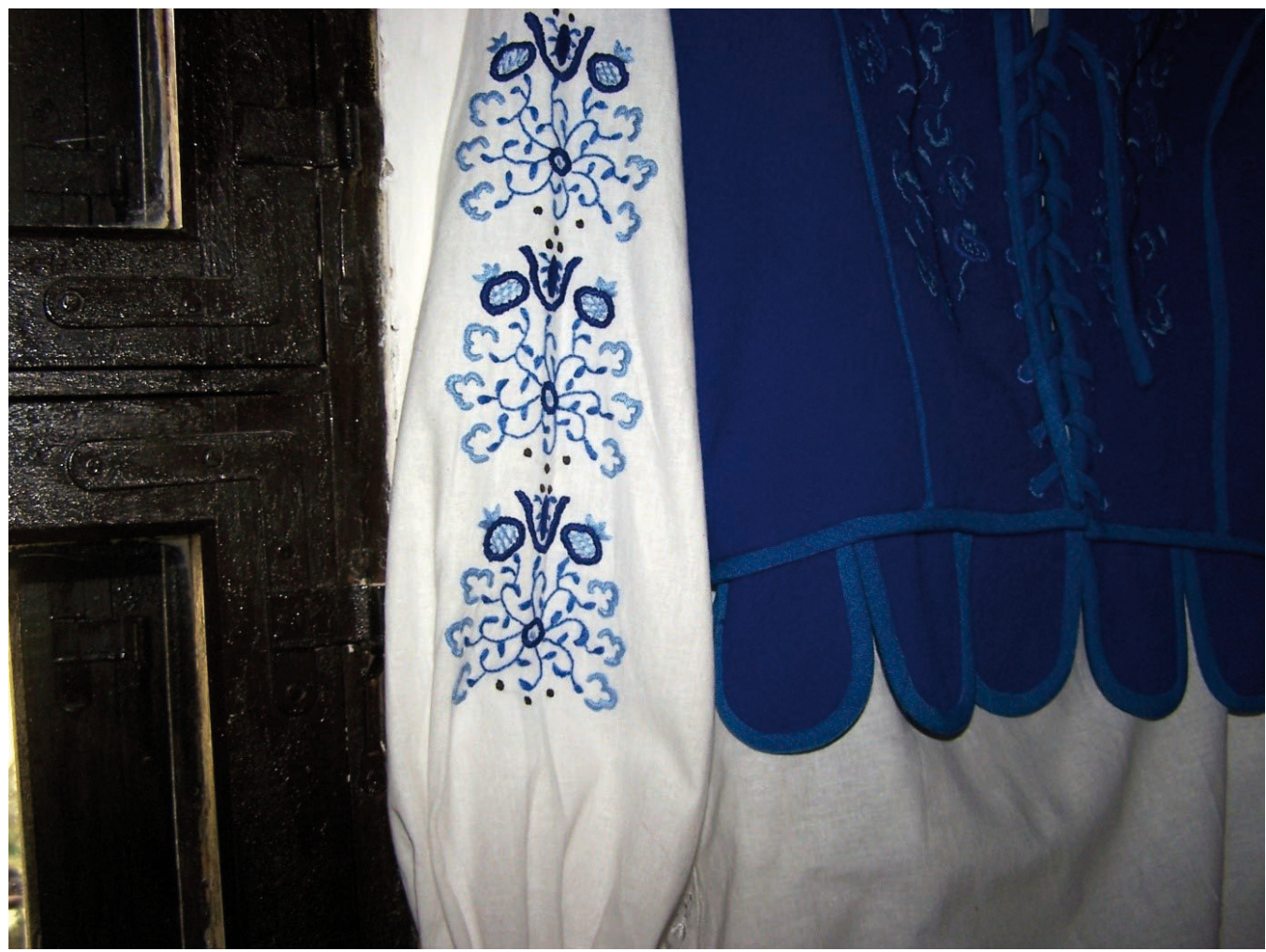

Fot. 17. Fragment błędnie zrekonstruowanego stroju i haftu krajeńskiego według projektu Jowity Kęcińskiej. W zbiorach Muzeum Ziemi Złotowskiej(fot. D. Angutek).

miejsce w przy padku listków w haftach kaszubskich. Można przyjąć, że nastąpiła w tym wypadku swobodna adaptacja motywów kaszubskich przy jednoczesnym twórczym przesunięciu odniesień do realiów pracy rolnika. Przemawia za tym domniemana geneza jego symboliki. Mianowicie „strzałki” imitują plewy. Czasem też kwadratowe, stosunkowo dużych rozmiarów punkciki i okrągły duży punkcik znajdujące się wewnątrz motywu oznaczają ziarna. Często na zewnątrz tego motywu występują symbolicznie rozsypane ziarna w postaci rombów i owalnych punktów. Ich obecność wewnątrz kłosa i rozsypanie na zewnątrz nawiązuje do ich właściwego przeznaczenia: są młócone, aby otrzymać z nich mąkę, a następnie pokarm. Z kolei „strzałki” mogą oznaczać powstałe po młócce plewy. Trzeba pamiętać, że Krajna była terenem rolniczym od wielu stuleci. Wielowiekowe niewolnictwo feudalne pozostawiło swój ślad w postaci wzorców pragmatyzmu. Nie sprzyjało natomiast utrwaleniu się idei romantycznej afirmacji przyrody. Chłop koncentrował się na przetrwaniu, a wszelkie ulepszenia i ozdobniki, które pojawiały się w sferze es- 
tetycznej, nawiązywały do przyczynowo postrzeganych przez niego zależności w przyrodzie. Motyw kłosów zboża przypominał, że to właśnie zboża stanowią dla chłopa podstawę żywieniową decydującą o przeżyciu.

Lilie. Ten drobny motyw złożony z dwóch rozchylonych płatków i półkolistego pełnego środka lub trzech pręcików często umyka uwadze przy pierwszej obserwacji. We współczesnym hafcie krajeńskim także występuje zgeometryzowany motyw lilii. Tworzy go centralnie umieszczony romb z dwoma rozchylonymi i smukłymi listkami powiązanymi u dołu pętelką w formie cienkiej linii. Najczęściej znajduje się on na zwieńczeniu lub u podstawy całej kompozycji (Fot. 13).

Dzwonki. Naturalistyczna forma jest tu bardzo czytelna, choć stylizacja jest podobna do drobnych lilii, z którymi mogą być mylone. Ich obecność nawiązuje do kościelnej symboliki, która bardzo często łączyła owoc granatu z dzwonkami, pełniącymi funkcję właściwą egzorcyzmowi. Kopaliński podaje za Księgą Wyjścia polecenie Boga dane Mojżeszowi: „Na dolnym brzegu szaty arcykapłana uczynisz wokoło jakby jabłuszka granatu z błękitu i ze szkarłatu i z karmazynu [...] poprzeplatane dokoła złotymi dzwonkami (Ex 28, 35)" (Kopaliński 1990: 104). Dlatego jeśli wprowadza się motyw dzwonków, powinna być zachowana zasada łączenia ich z motywem granatu. Zalecane jest unikanie samodzielnego stosowania tego motywu.

Rozsypane ziarna i wymłócone plewy. Częściowo opisałam te elementy, ale warto dodać, że w kłosie jest to pojedyncza owalna kropka pośrodku między plewami. Wszystkie ułożone są zawsze symetrycznie względem całej kompozycji.

Kółka. U podstaw całej kompozycji lub pojedynczych motywów występują pojedyncze kółeczka wypełnione haftem płaskim. Obwiedzione są konturem w postaci ściegu nazywanego „sznureczkiem” lub wąską obręczą- czasem wykonaną tak zwanym ściegiem zadzierzgiwanym.

Łodygi i czepy. Linie wykonane cienkim „sznureczkiem”, służą nie tylko do podkreślenia walorów dekoracyjnych haftu, ale przede wszystkim pełnią ważną funkcję połączeń wszystkich motywów tak, żeby tworzyły one zamknięte kompozycje. „Wąsy” zakończone są fantazyjny mi falistymi, czasem nieco ślimakowatymi zawijasami oraz pętelkami imitującymi czepy i wyginające się łodygi lilii i dzwonków. Motyw ten jest obecny także w hafcie szkoły wejherowskiej i wcześniejszych złotnicach oraz barokowym hafcie na obrusach ołtarzowych i ornatach, które były dla nich pierwowzorem. 
Nie wykluczam, że dawniej istniały jeszcze inne motywy, ale brak jest ich ewidencji w oryginalnych, zachowanych do naszych czasów źródłach.

Kolorystyka. Istnieje tu pewna dowolność. Co prawda układanie kolorów od najciemniejszego do najjaśniejszego we wzornictwie ludowym jest spotykane, lecz wydaje się, że w przy padku omawianego haftu obowiązuje przede wszystkim zasada kontrastu. Kostki, romby, drobne listki i strzałki oraz dzwonki naturalistyczne i schematyczne mogą być wykonane w trzech podstawowych barwach, subtelnie stonowanych. Kolor granatowy i błękitny oraz czarny występują zawsze w motywie owocu granatu, mimo że współczesne hafciarki mają prawo do pewnej dowolności, co wpływa na zachowanie żywotności każdego ludowego haftu.

Łodygi i czepy zawsze powinny być czarnego koloru, a nie, jak czasem się spotyka, brązowe, niebieskie, a nawet fioletowe. W ludowych tkaninach ze Skica i Świętej występuje bowiem tylko czarny kolor tego motywu. Poza tym o charakterze i swoistości tego haftu decyduje „wstrzemięźliwa” kolorystyka, co traktowałabym jako wskazówkę ważną dla zachowania specyfiki tego haftu. Najczęstsze kolory makówek to granatowy lub błękitny z ciemniejszym niebieskim, stosowanym na obrzeżach motywu. W zasadzie elementy te są zawsze dwubarwne.

Kompozycja motywów. Najważniejsza jest reguła dominacji. Motyw owocu granatu jest zwykle centralnym punktem. Możliwe jest także, zwłaszcza w drobnych pracach hafciarskich, pomijanie go na rzecz dwóch innych, np. makówki z dzwonkami lub zboża z kłosami i ziarnami w postaci drobnych rombów i strzałek (odczytywanych przeze mnie jako plewy).

Ponadto ornamentyka ludowa opiera się na symetrii, rytmie i żywym kontraście. Nie powiela się zatem głównego motywu w jednym rządku ściśle obok siebie z pominięciem innych podstawowych lub drobniejszych motywów towarzyszących. $\mathrm{W}$ wypadku haftu krajeńskiego najpierw komponuje się dowolną podstawową grupę motywów, lecz z zachowaniem zasady symetrii, a następnie tworzy się z nich rytmiczne ciągi. Tak więc motyw makówki zawsze tworzy symetryczną parę dwóch, czterech i więcej główek, a ich osią może być np. owoc granatu lub kłos zboża. Powściągliwość oraz harmonia i rytm w mnożeniu powtarzających się układów to kolejna reguła schematu. Obowiązuje ona nawet w bardzo bogatych haftach krajeńskich, np. na serwetach Ireny Cichończyk. Ważną cechą kompozycji haftu krajeńskiego jest listwa, która powinna występować pojedynczo na obrzeżach serwet, narzut, u dołu fartuchów i spódnic czy u dołu makatek. Haft może też być umieszczany na 
owalnych lub okrągłych serwetach w miejscu centralnym lub w zawsze pojedynczym wianuszku na brzegu tkaniny (nigdy nie tworzy się podwójnych czy potrójnych wianuszków lub pasów na brzegach np. obrusów).

Wielkość haftu i jego technika wykonania. O jego rozmiarze decydują dwie zasady. Zachowanie odpowiednich i wyważonych proporcji w stosunku do powierzchni całej tkaniny oraz w stosunku do wielkości poszczególnych elementów wzoru. Tak więc nie tylko dobór motywów pod względem ich symboliki (kolorystyki), ale także formalne wymogi zgeometryzowanej kompozycji stanowią ważne kryterium przy ocenie poprawności wykonanej pracy.

Technika. Techniką haftowania jest haft płaski (niepodwlekany i niezadzierzgiwany - wyjątek stanowią czasem zadzierzgiwane obwódki kółeczka), sznureczek („wąsy” czyli łodygi i czepy) oraz siateczka z nitek poprzetykanych krzyżowo, poprzecznie, imitujących ziarna wewnątrz makówki i owocu granatu. We fragmencie halki ze Skica widoczne są poprzeczne pojedyncze przęsełka, którymi przymocowano siateczkę do tkaniny (Fot. 1).

Opisane powyżej zasady oczywiście nie chronią hafciarek od popełniania błędów technicznych. Przejdę teraz do przedstawienia katalogu współcześnie najczęściej występujących uchybien. Fotografia nr 14 ilustruje często popełniany błąd przeszywania krzyżykami zamiast pojedynczym przęsełkami (Fot. 14; widoczne także na Fot. 1) siatki imitującej nasiona owocu granatu. Zabieg mocowania siateczki krzyżykiem należy do kanonu haftu kaszubskiego, a nie krajeńskiego.

Inny błąd polega na łączeniu motywów w taki sposób, że powstaje złudzenie istnienia kolejnego motywu w kompozycji zawierającej np. przylegające do siebie ciasno dwie lub cztery główki makówek lub układanie ich w rozetę. Natomiast zasadą haftu krajeńskiego jest mocne akcentowanie autonomiczności poszczególnych motywów w symetrycznej kompozycji (Fot. 15, 16).

Swoistej „rekonstrukcji” całego stroju kobiecego wraz z jego haftowanymi elementami dokonała filolog ze Słupska - profesor Jowita Kęcińska. Pojawiają się w tym hafcie motywy kaszubskie, takie jak rozmaite rozety oraz tulipany oraz elementy haftu z okolic Drawska i Debrzna oraz Pucka, nieobecne w historycznym ludowym hafcie złotowskim (Fot. 17). Jest to wyraz braku odpowiedzialności za zgodność z faktami historycznymi. Zapewne korzystała ona z projektów Marty Pierzyńskiej (znajdujących się w Muzeum Ziemi Złotowskiej), które jednak nigdy nie były przez nią popularyzowane i przyjęte przez hafciarki, które z nią współpracowały. 
Poczyniona przez Kęcińską trafna obserwacja, że haft krajeński wywodzi się z kaszubskiego, nie powinna uzasadniać swobodnego włączania do haftu złotowskiego elementów niepotwierdzonych w historycznych źródłach złotowskich. Wprawdzie wzory rękodzieła ludowego nigdy nie pokrywały się ze skostniałymi szablonami (także podobnie współczesne rekonstrukcje etnograficzne dopuszczają innowacje), ale dokonuje się tego drogą czerpania z wytworów np. ze skrzyń posagowych i innych wytworów rodzimego, lokalnego pochodzenia (Błachowski 1974). Chodzi bowiem o to, żeby zachować odrębność regionalną haftu, który pełni w wymiarze świadomościowym funkcję wzmacniającą poczucie tożsamości i funkcję różnicującą na tle sąsiednich regionów oraz w skali kraju. Zmiany, które wprowadzają hafciarki i Jowita Kęcińska w hafcie krajeńskim często nie są endogenne. Dowolnie naśladują zapożyczenia $\mathrm{z}$ innych regionów lub czerpią z projektów nieuznanych przez Niedżwieckiego za krajeńskie. Sądzę, że tego typu kompilacja nie zbiega się $\mathrm{z}$ inspiracjami wyrosłymi na rodzimym (regionalnym) gruncie kulturowym. Tak zaś powinno być, jeśli haft ma pozostać „wizy tówką” regionu, na czym zależy animatorom i lokalnym władzom krajeńskim. Zatem zmiany endogenne byłyby cenne i należy je akceptować, pod warunkiem, że mieszczą się w ramach zasad zrekonstruowanych przez etnografów dla sztuki ludowej w ogóle.

\section{Rozważania końcowe}

Zamykając moją wypowiedź pragnę wskazać na dylemat, przed którym staje część etnografów: zachować wierność faktom historycznym czy dokonać interwencji inicjującej zmianę kulturową. Badacz nie powinien, jak uczy rzemiosło, jak zakłada się w podejściu naukowym, wprowadzać zmian w kulturze, którą bada. Ma być wiernym dokumentalistą i interpretatorem. Skłaniam się ku tej dyrektywie i uważam, że warto przekonywać część etnografów, aby nie popierali przemian, które rozbijają wzór ludowy. Aby żywiołową twórczość, nieopartą na żadnym kanonie, oddzielali od tej pierwotnej i dokumentowali ją jako odrębne zjawisko, które, za Ericem Hobsbawmem, nazywam tradycją wytworzoną (wynalezioną) (Hobsbawm 2008).

Rozwijający się w Polsce od początku lat 80 . XX wieku regionalizm jest jednym $\mathrm{z}$ wiodących współczesnych zjawisk kulturowych i procesów społecznych. Jedną ze sprężyn dynamizujących rozwój regionów i lokalnych „małych ojczyzn” jest wspomniana tradycja wytworzona. Tego rodzaju tradycja, paradoksalnie całkiem świeżej daty, 
polega na świadomym przeszczepianiu na własny teren elementów niespecyficznych dla danego obszaru, pochodzących z innych regionów i propagowanie ich jako własnej tradycji. Wdraża się ją do współczesnego lokalnego obiegu oraz masowo prezentuje na różnego rodzaju imprezach rozrywkowych i kulturalno-oświatowych w regionie i całym kraju, a nawet poza jego granicami. Drugim sposobem generowania tradycji wytworzonej jest wynajdywanie tradycji od początku, bez historycznych podstaw.

Z tradycją wytworzoną w znaczeniu pierwszym spotykamy się na terenie obecnego powiatu sępoleńskiego i nakielskiego. Krajniacy z Krajny Nakielskiej obejmującej dwa wymienione powiaty zapożyczyli wzory oryginalnego haftu, który występował pierwotnie tylko w okolicach Świętej i propagują je jako wytwór właściwy całemu regionowi krajeńskiemu. Do końca lat 80 . XX wieku dość wiernie zachowywano wzory z Krajny Złotowskiej, jednak później zaczęto dowolnie je zmieniać; nawet spotykane są takie warianty tego haftu, które nie mają żadnych podstaw historycznych, np. wzory w tonacjach czerwonych, białych i złoto-brązowych, a nawet wielobarwne. Ponadto wplata się w kompozycje z gruntu nieludowe rozwiązania oraz motywy, które nie występują w historycznym hafcie ludowym z okolic Złotowa. Jakkolwiek intencją hafciarek jest dochowanie wierności wzorom ludowym, są one niekonsekwentne w utrzymaniu tej konwencji.

Zapożyczanie i przekształcanie wzorów w sposób dowolny, niezaplanowany, fragmentaryczny, bez wskazówek etnografa, nie przysłużyło się niestety do zachowania zgodności haftu powstałego w ostatnich dwudziestu latach (a uchodzącego w potocznej opinii za „krajeński”) z jakimkolwiek w miarę wiernym kanonem ludowym (por. Klekot 2012). Mamy do czynienia z nowym zjawiskiem masowym, które jak na razie umyka obserwacji, dokumentowaniu i animowaniu przez etnografów. W najbliższej przyszłości warto by było zatem dokonać rzetelnego naukowego rozróżnienia między tradycją ludową („pierwotną”) i wytworzoną, by na tej podstawie prowadzić badania m.in. inwentaryzacyjne. Dałoby to zaplecze teoretyczne dla etnografów pragnących animować te dziedziny rękodzieła ludowego, które jeszcze czekają na opracowanie. Innym postulatem jest ocalenie pierwotnego kanonu przed rozcieńczeniem jego treści w ramach twórczości masowej, rozwijanej na bazie inspiracji czerpanych spoza opisanego wzoru i stylu ludowego haftu krajeńskiego.

Istnieją zatem co najmniej trzy powody dla utrzymania dawnych ludowych wzorów krajeńskich: (1) zachowanie oryginalnej specyfiki i odrębności regionalnej tego wzornictwa hafciarskiego; (2) podtrzymanie istniejącej od początku badań i prac re- 
konstrukcyjnych innych etnografów tendencji do podjęcia i kontynuowania ludowego kanonu; (3) uwzględnienie ambicji hafciarek pragnących utrzymania swoich prac w kanonie ludowym (Angutek 2018; Klekot 2012). Ponadto ważne jest, aby nie dopuścić do „skostnienia” wzoru haftu krajeńskiego. Dopuszczalne byłoby w przyszłości włączenie do niego dwóch nowych motywów, towarzyszących trzem głównym, wywiedzionym z wzorów umieszczanych na foremkach do masła i skrzyniach posagowych pochodzących z Krajny Złotowskiej. Tego typu ingerencja pozostawałaby w konwencji wzornictwa ludowego, co opiszę i zamieszczę w planowanym przez mnie Wzorniku (po skonsultowaniu się z ekspertami w tej dziedzinie). Nie opowiadam się zatem za „zamrożeniem” wzoru ludowego haftu z Krajny, ponieważ jako część dziedzictwa kulturowego tego obszaru Krajny winien być jego elementem dynamicznym, chętnie podejmowanym przez hafciarki. Sugeruję jedynie ingerencję rozważną, a zatem zgodną z zasadami twórczości ludowej, by włączyć elementy, które nie będą burzyły trzech celów uzasadniających utrzymanie kanonu ludowego. Natomiast spontaniczna twórczość zaliczana przeze mnie do tradycji wytworzonej powinna jako taka być pozostawiona inwencji uczestników kultury, a przy tym być osobno inwentaryzowana przez muzealników jako świadectwo naszych czasów.

\section{Bibliografia}

Angutek, D. (2018). Tradycje wytworzone w Polsce rodzącej się ponowoczesności. Bydgoszcz: Oficyna Epigram (w przygotowaniu).

Błachowski, A. (1974). Skarby w skrzyni malowanej czyli o sztuce ludowej inaczej. Warszawa: Ludowa Spółdzielnia Wydawnicza.

Błachowski A. (2007).Z historii haftów kaszubskich - geneza i formy. W: Obracht-Prondzyński, C. (red.),Ziemia Człuchowska - Kaszuby - Pomorze. Odziejach, kulturze iludziach, ss. 191-242. Człuchów-Gdańsk: Instytut Kaszubski - Muzeum Regionalne w Człuchowie.

Dzikowski, S. (1909). Z wędrówek po miastach polskich. Świat, 41, 13.

Forstner, D. (1990). Granat, drzewo i owoc. W: Idem, Świat symboliki chrześcijańskiej (przeł. W. Zakrzewska $\mathrm{i}$ in.), ss. 163-166.Warszawa: PAX.

Gulgowska, T. (2010). Jak na to wpadłam, żeby wprowadzić rzemiosło domowe. Das Land, 18, 185. Gulgowski, I. (2012). O nieznanym ludzie w Niemczech. Przyczynek do ludoznawstwa i krajoznawstwa Kaszub (przeł. M. Darska-Łogin). Reprint w: J. Borzyszkowski (red.), Von einem unbe- 
kannten Volke in Deutschland. Ein Beitrag zur Volks - und Landeskunde der Kaschubei, Gdańsk: Instytut Kaszubski w Gdańsku 1911.

Hobsbawm, E. (2008). Wprowadzenie. W: E. Hobsbawm, T. Ranger (red.), Tradycja wynaleziona (przeł. M. i F. Godyń), ss. 9-23. Kraków: WUJ.

Jackowski, A. (2007). Polska sztuka ludowa. Warszawa: Wydawnictwo Naukowe PWN.

Judziewicz, M., Skorupski, H., Klonowski, A. (1955). Katalog wystawy sztuki ludowej Warmii i Mazur. Olsztyn: Muzeum Mazurskie.

Klekot, E. (2012). Etnodizajn - kolejne konfiguracje sztuki ludowej. Etnografia Nowa, 4, 39-47.

Klinger, W. (1931). Doroczna obrzędowość ludowa a tradycje grecko-rzymskie. Kraków: Gebethner i Wolff.

Kopaliński, W. (1990). Granat(owiec). W: Idem, Słownik symboli, ss. 103-105. Warszawa: Wiedza Powszechna.

Kossak, Z. (1958). Rok polski. Obyczaj i wiara. Warszawa: PAX.

Majkowski, A. (1909). Rozmaitości. Wystawa haftów kaszubskich. Gryf, 4, 126.

Niedżwiecki, J. (1977a). Wybrane zagadnienia sztuki ludowej Krajny i Pałuk. Rocznik Nadnotecki, VIII, 1, 114-129.

Niedżwiecki, J. (1977b). Zagadnienia współczesnej sztuki ludowej Krajny i Pałuk. Koszalińskie Zeszyty Muzealne, 7, 33-48.

Niedżwiecki, J. (2001). Odzież i strój ludowy Krajniaków Złotowskich. Kronika Wielkopolska, 3, $168-171$.

Stomma, L. (1981). Słońce rodzi się 13 grudnia. Warszawa: Ludowa Spółdzielnia Wydawnicza. Stomma, L. (1986). Antropologia kultury wsi polskiej XIX wieku. Warszawa: PAX.

Zadrożyńska, A. (1986). Powtarzać czas początku, cz.1. O świętowaniu dorocznych świąt w Polsce. Warszawa: Wydawnictwo Spółdzielcze.

Zadrożyńska, A. (2000). Światy, zaświaty. O tradycji świętowań w Polsce. Warszawa: Twój Styl. 
